\title{
Iodothyronine Metabolism in Rat Liver Homogenates
}

\author{
Michael M. Kaplan and Robert D. Utiger, Endocrine Section, \\ Department of Medicine, University of Pennsylvania School of Medicine, \\ Philadelphia, Pennsylvania 19104
}

\begin{abstract}
A B S T R A C T To investigate mechanisms of extrathyroidal thyroid hormone metabolism, conversion of thyroxine $\left(\mathrm{T}_{4}\right)$ to $3,5,3^{\prime}$-triiodothyronine $\left(\mathrm{T}_{3}\right)$ and degradation of $3,3^{\prime}, 5^{\prime}$-triiodothyronine $\left(\mathrm{rT}_{3}\right)$ were studied in rat liver homogenates. Both reactions were enzymatic. For conversion of $\mathrm{T}_{4}$ to $\mathrm{T}_{3}$, the $K_{m}$ of $\mathrm{T}_{4}$ was $7.7 \mu \mathrm{M}$, and the $V_{\max }$ was $0.13 \mathrm{pmol} \mathrm{T}_{3} /$ min per mg protein. For $\mathrm{rT}_{3}$ degradation, the $K_{m}$ of $\mathrm{rT}_{3}$ was $7.5 \mathrm{nM}$, and the $V_{\max }$ was $0.36 \mathrm{pmol} \mathrm{rT}_{3} / \mathrm{min}$ per mg protein. Production of $\mathrm{rT}_{3}$ or degradation of $T_{4}$ or $T_{3}$ was not detected under the conditions employed. $\mathrm{rT}_{3}$ was a potent competitive inhibitor of $\mathrm{T}_{4}$ to $\mathrm{T}_{3}$ conversion with a $K_{i}$ of $4.5 \mathrm{nM} ; 3,3^{\prime}$ diiodothyronine was a less potent inhibitor of this reaction. $\mathrm{T}_{4}$ was a competitive inhibitor of $\mathrm{rT}_{3}$ degradation with a $K_{i}$ of $10.2 \mu \mathrm{M}$. Agents which inhibited both reactions included propylthiouracil, which appeared to be an allosteric inhibitor, 2,4-dinitrophenol, and iopanoic acid. Sodium diatrizoate had a weak inhibitory effect. No inhibition was found with $\alpha$-methylparatyrosine, $\mathrm{Fe}^{+2}, \mathrm{Fe}^{+3}$, reduced glutathione, $\beta$-hydroxybutyrate, or oleic acid.
\end{abstract}

Fasting resulted in inhibition of $\mathrm{T}_{4}$ to $\mathrm{T}_{3}$ conversion and of $\mathrm{rT}_{3}$ degradation by rat liver homogenates which was reversible after refeeding. Serum $\mathrm{T}_{4}, \mathrm{~T}_{3}$, and thyrotropin concentrations fell during fasting, with no decrease in serum protein binding as assessed by a $T_{3^{-}}$ charcoal uptake. There was no consistent change in serum $\mathrm{rT}_{3}$ concentrations. Dexamethasone had no effect in vitro. In vivo dexamethasone administration resulted in elevated serum $\mathrm{rT}_{3}$ concentrations after 1 day, and after 5 days, in inhibition of $\mathrm{T}_{4}$ to $\mathrm{T}_{3}$ conversion and $\mathrm{rT}_{3}$ degradation without altering serum $\mathrm{T}_{4}, \mathrm{~T}_{3}$, or thyrotropin concentrations. Endotoxin treatment had no effect of iodothyronine metabolism in liver homogenates. In kidney homogenates the reaction rates and response to propylthiouracil in vitro were similar to

This work was presented in part at the 59th Meeting of the Endocrine Society, Chicago, Ill., June 1977.

Dr. Kaplan's present address is Thyroid Unit, Department of Medicine, Peter Bent Brigham Hospital, Boston, Mass. 02115.

Received for publication 24 March 1977 and in revised form 21 September 1977. those in liver. No significant $T_{4}$ to $T_{3}$ conversion or $\mathrm{rT}_{3}$ production or degradation could be detected in other tissues.

These data suggest that one iodothyronine 5 '-deiodinase is responsible for both $T_{4}$ to $T_{3}$ conversion and $\mathrm{rT}_{3}$ degradation in liver and, perhaps, in kidney. Alterations in serum $\mathrm{T}_{3}$ and $\mathrm{rT}_{3}$ concentrations induced by drugs and disease states may result from decreases in both $\mathrm{T}_{3}$ production and $\mathrm{rT}_{3}$ degradation consequent to inhibition of a single reaction in the pathways of iodothyronine metabolism.

\section{INTRODUCTION}

Deiodination is a major mechanism of thyroxine $\left(\mathrm{T}_{4}\right)^{1}$ disposal in the human and the rat $(1,2)$. The active thyroid hormone, 3,5,3'-triiodothyronine $\left(\mathrm{T}_{3}\right)$ is produced by $5^{\prime}$-deiodination of $\mathrm{T}_{4}$, whereas a calorigenically inactive compound, 3,3', $5^{\prime}$-triiodothyronine (reverse- $\mathrm{T}_{3}, \mathrm{rT}_{3}$ ), is produced by 5 -deiodination. Rates of removal of the 5'- and 5-iodine of $\mathrm{T}_{4}$ are approximately equal in humans and rats $(3,4)$, but these processes do not occur randomly. Decreased serum $\mathrm{T}_{3}$ concentrations, resulting from decreased peripheral 5 '-deiodination of $T_{4}$, are found in patients with a variety of illnesses, during fasting and in fetal life (4-21). In these situations, serum $\mathrm{rT}_{3}$ concentrations are usually elevated, suggesting diversion of $\mathrm{T}_{4}$ to the inactivating 5deiodinating pathway $(4,7,8,10,12,15,16,18,20,21)$. However, elevated serum $\mathrm{rT}_{3}$ concentrations in two such situations, hepatic cirrhosis and fasting, were recently shown $(4,22)$ to result from decreased $\mathrm{rT}_{3}$ degradation rather than increased $\mathrm{rT}_{3}$ production. In fetal sheep, the metabolic clearance rate of $\mathrm{rT}_{3}$ is low, relative to adult sheep (23), and, although the production rate of $\mathrm{rT}_{3}$ is elevated, it is not markedly different from the adult rate if expressed as a fraction of the daily $T_{4}$ production $(0.32$ for the fetal sheep vs. 0.25 for the adults).

'Abbreviations used in this paper: PTU, 2-propyl-6thiouracil; 3,5- $\mathrm{T}_{2}, 3,5$-diiodothyronine; 3,3'- $\mathrm{T}_{2}, 3,3^{\prime}$-diiodothyronine; $\mathrm{T}_{3}, 3,5,3^{\prime}$-triiodothyronine; $\mathrm{rT}_{3}$ (reverse $\mathrm{T}_{3}$ ), 3,3', $5^{\prime}$ triiodothyronine; $\mathrm{T}_{4}$, thyroxine; $\mathrm{TSH}$, thyrotropin. 
Many tissues, including liver, kidney, heart, skeletal muscle, leukocytes, and fibroblasts, are capable of deiodinating $\mathrm{T}_{4}$ in vitro $(24-39)$. The techniques used to demonstrate $T_{4}$ deiodination in these studies included incubation of tissue homogenates, tissue slices, dispersed cells, and whole organ perfusion. $T_{3}$ has been identified as a deiodination product of $\mathrm{T}_{4}(24,26,27$, $29,31,35,36)$. At the subcellular level, both $\mathrm{T}_{4}$ deiodination and $T_{4}$ to $T_{3}$ conversion were localized to the microsomal fraction of liver homogenates (37-39), whereas production of $\mathrm{rT}_{3}$ from $\mathrm{T}_{4}$ has been found in the mitochondrial and soluble fractions of a liver homogenate preparation (36). Most of these reports contain relatively little data concerning the characteristics and kinetics of the reactions studied or information about $\mathrm{T}_{4}$ metabolism in vitro in situations such as starvation or treatment with drugs which alter extrathyroidal $\mathrm{T}_{4}$ or $\mathrm{rT}_{3}$ metabolism in man.

The original aim of this study of $T_{4}$ metabolism in rat liver homogenates was to obtain information about $\mathrm{T}_{3}$ and $\mathrm{rT}_{3}$ production, inasmuch as the nature of these processes and their regulation are undefined. It soon became clear that, if $\mathrm{rT}_{3}$ was being produced, it was also being destroyed too rapidly for its production to be observed. Further experiments showed that factors which inhibited $\mathrm{T}_{4}$ to $\mathrm{T}_{3}$ conversion also inhibited $\mathrm{rT}_{3}$ degradation. In light of these observations and those of Cavalieri et al. (36) and Chopra et al. (40), who have reported that $5^{\prime}$-deiodination is a major pathway of $\mathrm{rT}_{3}$ degradation, the experiments were extended to test the hypothesis that $\mathrm{T}_{4}$ to $\mathrm{T}_{3}$ conversion and $\mathrm{rT}_{3}$ degradation reflect activities of the same enzyme. The results support this hypothesis. This report, therefore, describes biochemical characterization of $\mathrm{T}_{4}$ to $\mathrm{T}_{3}$ conversion and $\mathrm{rT}_{3}$ degradation reactions in homogenates of rat liver and other tissues and studies of these reactions in rats in situations of altered extrathyroidal iodothyronine metabolism in vivo.

\section{METHODS}

Materials. $\quad \mathrm{rT}_{3}$ was a gift of Dr. R. Meltzer, Warner-Lambert Research Institute, Morris Plains, N. J.; 3,3'-diiodothyronine $\left(3,3^{\prime}-\mathrm{T}_{2}\right)$ was a gift of Dr. H. Cahnmann, National Institutes of Health, Bethesda, Md.; 3,5-diiodothyronine (3,5- $\left.\mathrm{T}_{2}\right)$ was obtained from Travenol Laboratories, Inc., Morton Grove, Ill.; iopanoic acid was a gift of Dr. W. Blakemore, SterlingWinthrop Research Institute, Rensselaer, N. Y.; and ${ }^{125} \mathrm{I}_{-} \mathrm{rT}_{3}$ was purchased from Abbott Laboratories, Chemical Div., North Chicago, Ill.

Preparation of homogenates. Liver homogenates were prepared by a modification of the method of Visser et al. (26). Rats were sacrificed by decapitation. Serum was separated from the trunk blood and stored at $-4^{\circ} \mathrm{C}$. The livers were removed, minced in cold $0.05 \mathrm{M}$ Tris, $\mathrm{pH} 7.6$, washed twice and homogenized in $3 \mathrm{vol}$ of the same buffer (wt/vol) with three to four strokes in a glass homogenizer with a motordriven Teflon pestle. In one group of experiments, a series of different buffers were used (see below). The crude homogenate was centrifuged at $2000 \mathrm{~g}$, the sediment was discarded, and the supernate, referred to hereafter as the liver homogenate, was used for subsequent incubations. It was assumed to contain cytosol, microsomes, mitochondria, and membrane fragments, but not whole cells or nuclei. Homogenates of other tissues were prepared by the same procedure. The liver homogenates had a protein content of $28 \pm 1 \mathrm{mg} / \mathrm{ml} \mathrm{SE}$, and that of the kidney homogenates was $18 \pm 1 \mathrm{mg} / \mathrm{ml}$. All incubations were performed immediately after preparation of the homogenates.

Incubation procedure. Incubations were carried out with $2 \mathrm{ml}$ homogenate per incubation tube in a $37^{\circ} \mathrm{C}$ water bath (except for the temperature dependence studies) after preincubation for $5 \mathrm{~min}$ at $37^{\circ} \mathrm{C}$ before addition of any reagents. Homogenates from individual rats were incubated separately in the in vivo studies but were pooled for kinetic and inhibition studies. In the latter, four to five rat livers were used, and the incubations were done in triplicate or quadruplicate. Iodothyronines were dissolved in $0.25 \%$ bovine serum albumin (BSA), $0.01 \mathrm{M} \mathrm{PO}_{4}, 0.15 \mathrm{M} \mathrm{NaCl}, \mathrm{pH} 7.5$ (BSA-phosphate-buffered saline). Other added compounds were dissolved in BSA-phosphate-buffered saline, water or ethanol. These substances were added to the homogenates in volumes of $10-60 \mu \mathrm{l} / \mathrm{ml}$ homogenate at the beginning of the incubation period; equal volumes of vehicle were added to control homogenates. 200-500- $\mu$ l aliquots of the homogenate were removed after various time intervals and immediately mixed with $2 \mathrm{vol}$ of $95 \%$ ethanol and stored at $4^{\circ} \mathrm{C}$ until assayed. Unincubated homogenate was also mixed with 2 vol $95 \%$ ethanol for use as a blank to which standards for the hormone radioimmunoassays were added. Slow formation of a fine precipitate occurred in the ethanol phase for about $24 \mathrm{~h}$. This interfered in the assays, so the samples were stored at least $24 \mathrm{~h}$ before assay, and they were centrifuged just before assay to remove this precipitate. Recovery of iodothyronines added to prewarmed homogenates and immediately extracted and assayed as below was $82 \pm 7 \%$ for $\mathrm{T}_{4}, 62 \pm 2 \%$ for $\mathrm{rT}_{3}$, and $75 \pm 5 \%$ for $\mathrm{T}_{3}$. All measured hormone concentrations were corrected for recovery.

$T_{4}, T_{3}$, and $r T_{3}$ determinations in liver extracts. To duplicate tubes were added: (a) $100 \mu \mathrm{l}$ of ${ }^{125} \mathrm{I}_{-} \mathrm{T}_{4},{ }^{125} \mathrm{I}-\mathrm{rT}_{3}$, or ${ }^{125} \mathrm{I}_{-} \mathrm{T}_{3}$ dissolved in $0.4 \%$ BSA, $0.05 \mathrm{M} \mathrm{K}_{2} \mathrm{HPO}_{4}$, pH 7.4 (BSA-KPO ${ }_{4}$ ); (b) $100 \mu \mathrm{l}$ of anti- $\mathrm{T}_{4}$, anti- $\mathrm{T}_{3}$, or anti-r $\mathrm{T}_{3}$ serum diluted in $\mathrm{BSA}$ $\mathrm{KPO}_{4}$ containing $0.05 \mathrm{M}$ EDTA to give $35-50 \%$ binding of labeled hormone; (c) $50 \mu \mathrm{l}$ of $\mathrm{T}_{4}, \mathrm{~T}_{3}$, or $\mathrm{rT}_{3}$ standards diluted in blank ethanol extract of liver or $50 \mu \mathrm{l}$ of homogenate extract or dilution thereof; and $(d) \mathrm{BSA}-\mathrm{KPO}_{4}$ to make a final volume of $1 \mathrm{ml}$. Tubes were incubated for $18-24 \mathrm{~h}$ at $4^{\circ} \mathrm{C}$ and free and antibody-bound labeled hormone was separated with goat anti-rabbit IgG. The sensitivity of these assays was $60-80 \mathrm{pg}$ $\mathrm{T}_{4}, 8-15 \mathrm{pg} \mathrm{T}_{3}$, and 4-8 $\mathrm{pg} \mathrm{rT}_{3}$. In the $\mathrm{T}_{3}$ and $\mathrm{rT}_{3}$ assays, varying the volume of extract in the assay tubes from 10 to 75 $\mu \mathrm{l}$ resulted in a linear dose-response; with volumes $\geqslant 100 \mu \mathrm{l}$ there was under-recovery.

Kinetic studies. In the calculation of reaction rates, the differences between initial measured $\mathrm{T}_{3}$ or $\mathrm{rT}_{3}$ concentrations and those at later times, specified below, were used. Addition of reagents, mixing, and sampling took $\cong 7 \mathrm{~s}$. This was taken as zero in the $T_{4}$ to $T_{3}$ conversion experiments, but was taken as $7 \mathrm{~s}$ in the $\mathrm{rT}_{3}$ degradation experiments, with initial concentrations calculated by extrapolation. Initial extracts taken after addition of $T_{4}$ had immunoreactivity for $T_{3}$ and $\mathrm{rT}_{3}$ which increased in proportion to the added $\mathrm{T}_{4}$. It cannot be determined how much of this activity was due to contamination of the $T_{4}$ preparation and how much was intrinsic $T_{4}$ cross-reactivity. In that the $\mathrm{T}_{3}$ immunoreactivity did not change over 120 min when $T_{4}$ was incubated with buffer or heat inactivated 
homogenate, it was felt that subtracting the initial concentration from subsequent ones gave a valid measurement of $T_{3}$ production. The initial $T_{3}$ immunoreactivity limited the range of added $\mathrm{T}_{4}$ concentrations which could be used, because, at high initial $\mathrm{T}_{4}$ concentrations, the change in $\mathrm{T}_{3}$ concentrations became a progressively smaller fraction of the initial $T_{3}$ immunoreactivity. For this reason, the concentration of $T_{4}$ used in the inhibition and in vivo studies had to be less than the $K_{m}$ of $\mathrm{T}_{4}$.

The $\mathrm{rT}_{3}$ immunoreactivity after addition of $\mathrm{T}_{4}$ to homogenates did not change over $120 \mathrm{~min}$. In that $\mathrm{rT}_{3}$ was degraded so rapidly (see below), this was considered to represent $T_{4}$ cross-reactivity in the $\mathrm{rT}_{3}$ assay, and thus did not invalidate measurements of changes in $\mathrm{rT}_{3}$ concentrations in the presence of $T_{4}$. A similar interaction of $3,3^{\prime}-T_{2}$ was noted in the $\mathrm{rT}_{3}$ assay.

Endogenous $\mathrm{T}_{4}$ concentrations in rat liver have been estimated to be $11.05 \pm 1.63 \mathrm{ng} / \mathrm{g}$ whole liver $(41)$, which would be $<5 \mathrm{nmol} /$ liter of homogenate, $<1 \%$ of the $\mathrm{T}_{4}$ added in the present experiments. No information is available about endogenous hepatic $\mathrm{rT}_{3}$ concentrations. They are probably very low; even with the unlikely assumption that the entire difference between blank liver extract and buffer in the $\mathrm{rT}_{3}$ assay was due to endogenous $\mathrm{rT}_{3}$, the endogenous $\mathrm{rT}_{3}$ concentration would contribute $<0.8 \mathrm{nmol} / \mathrm{liter}$ homogenate. Once again, this concentration is small compared to those used in these experiments. For the above reasons, endogenous $\mathrm{T}_{4}$ and $\mathrm{rT}_{3}$ were felt to be negligible in the kinetic calculations and were ignored.

The determination of $K_{m}$ and $K_{i}$ values for $\mathrm{rT}_{3}$ was complicated by the substantial decrease in $\mathrm{rT}_{3}$ concentration during the reaction. This problem was managed by keeping the incubation periods as short as possible in the experiments which measured these constants, and by using the mean of the initial and final $\mathrm{rT}_{3}$ concentrations in the kinetic plots as suggested by Segel (42).

$T_{4}, \mathrm{~T}_{3}$, and $r \mathrm{~T}_{3}$ determinations in serum. Double antibody assays were performed as previously described (43-45). The anti- $\mathrm{T}_{4}$ antibody was purchased from Endocrine Sciences, Tarzana, Calif. The $\mathrm{rT}_{3}$ assay was modified from the assay for $\mathrm{rT}_{3}$ in human serum described elsewhere (45), using $200 \mu \mathrm{l}$ serum, $75 \mu \mathrm{l}$ anti-r $\mathrm{T}_{3}$ antiserum diluted 1:5000, ${ }^{125} \mathrm{I}-\mathrm{T}_{3}$ of high specific activity $(\sim 800 \mu \mathrm{Ci} / \mu \mathrm{g})$, and $200 \mu \mathrm{g} 8$-anilino-1-naphthalenesulfonic acid in each assay tube. Sensitivity was $2-4 \mathrm{pg} / \mathrm{tube}$ or $1-2 \mathrm{ng} / \mathrm{dl}$ of serum. Cross-reactivity with $\mathrm{T}_{4}$ was $0.04 \%$, and cross-reactivity with $\mathrm{T}_{3}$ was $<0.01 \%$. There was $\mathrm{rT}_{3}$ immunoreactivity in all but one of 138 rat serum samples tested. In these 137 , the measured $\mathrm{rT}_{3}$ concentrations ranged from 1.6 to $7.2 \mathrm{ng} / \mathrm{dl}$, with a mean of $4.0 \mathrm{ng} / \mathrm{dl}$. Because $0.04 \% \mathrm{~T}_{4}$ crossreactivity combined with a serum $\mathrm{T}_{4}$ concentration of $5 \mu \mathrm{g} / \mathrm{dl}$ accounts for $2 \mathrm{ng} \mathrm{rT} / \mathrm{dl}$, a substantial fraction of the total, the measured $\mathrm{rT}_{3}$ concentrations were corrected by subtracting $0.04 \%$ of the $\mathrm{T}_{4}$ concentration in each serum. The corrected mean normal rat serum $\mathrm{rT}_{3}$ concentration was $1.8 \pm 0.9 \mathrm{ng} / \mathrm{dl}$ SD. Serum thyrotropin (TSH) was also measured by radioimmunoassay, using reagents supplied by the National Pituitary Agency (NPA). Results are expressed in nanograms of the NPA RP-1 rat pituitary TSH standard/milliliter serum. Protein was measured by the method of Lowry et al. (46), using BSA as a standard.

Serum $\mathrm{T}_{3}$ concentrations in the normal rats were higher than reported by others (47). The assay method used in these studies often yielded lower results in other normal rats, but the values reported here were consistently obtained when the sera were measured in two to three different assay runs. Serum $\mathrm{rT}_{3}$ concentrations in the range of $2 \mathrm{ng} / \mathrm{dl}$ are consistent with a recent report (48) of immeasurable rat serum $\mathrm{rT}_{3}$ using an assay with a sensitivity of $6 \mathrm{ng} / \mathrm{dl}$. The low values and the necessity of using a substantial correction for $\mathrm{T}_{4}$ cross-reactivity require that the $\mathrm{rT}_{3}$ concentrations be interpreted very cautiously.

To assess serum protein binding of $T_{3}, a_{3}$-charcoal uptake was performed. The method was adapted for rat serum from that of Bermudez et al. (6). $100 \mu \mathrm{l}$ serum was incubated with $7-8,000 \mathrm{cpm}^{125} \mathrm{I}^{-} \mathrm{T}_{3}$ in $50 \mu \mathrm{l} 0.1 \% \mathrm{BSA}, 0.075 \mathrm{M} \mathrm{Na} \mathrm{PO}_{4}, \mathrm{pH} 7.4$, for $30 \mathrm{~min}$ at $37^{\circ} \mathrm{C}$. $700 \mu \mathrm{l}$ of $0.025 \%$ dextran T-70 (Pharmacia Fine Chemicals, Div. of Pharmacia, Inc., Piscataway, N. J.) and $0.05 \%$ charcoal in the same buffer was added, and the mixture was incubated at room temperature for $20 \mathrm{~min}$ and centrifuged at $2,000 \mathrm{rpm}$ for $15 \mathrm{~min}$. The supernate was then aspirated, and the charcoal was counted. This method was validated by comparing normal rat serum (total serum $\mathrm{T}_{4} 5.6 \pm 1.6 \mu \mathrm{g} / \mathrm{dl} \mathrm{SD}$ ) with serum from rats made hyperthyroid by injection of $\mathrm{T}_{4}$, $10 \mu \mathrm{g} / 100 \mathrm{~g} /$ day s.c. for 12 days (total serum $\mathrm{T}_{4} 8.9 \pm 2.1 \mu \mathrm{g} / \mathrm{dl}$ ) and with serum from thyroidectomized rats (total serum $\mathrm{T}_{4} 1.7$ $\pm 0.3 \mu \mathrm{g} / \mathrm{dl}$ ). The mean $\mathrm{T}_{3}$-charcoal uptakes were: normal, $39.1 \pm 3.5 \% \mathrm{SD} ; \mathrm{T}_{4}$-treated, $53 \pm 2.2 \%$; and thyroidectomy 26.5 $\pm 3.8 \%$.

\section{In vivo studies}

Fasting. Groups of five 200-250-g male Sprague-Dawley rats were fasted for 1-4 days with free access to tap water. Other groups were fasted for 3 days, then fed with Wayne Lab-Blox (Allied Mills, Inc., Chicago, Ill.) for 1-6 days before sacrifice. A control group of five fed rats from the same animal shipment as each experimental group was sacrificed simultaneously. Fasting was begun at 9 A.M., and the animals were sacrificed at the same time. Liver homogenates from each rat were incubated with $1.3 \mu \mathrm{M} \mathrm{T}$, and aliquots were removed and extracted with ethanol at 0,15 , and $30 \mathrm{~min}$. In this period the reaction rate was reasonably constant (see Results). Liver homogenates from each rat were also incubated with $1.54 \mathrm{nM}$ $\mathrm{rT}_{3}$, aliquots being taken at 0 and $3 \mathrm{~min}$. With these incubation conditions $\mathrm{rT}_{3}$ degradation was reliably measurable. The concentration of $\mathrm{rT}_{3}$ was chosen to avoid extremes of the assay curve in a 3-min incubation, and the time was chosen as a compromise because small concentration changes, difficult to measure reliably, resulted from shorter incubations, and gross nonlinearity in the reaction rate was found after longer incubations (see below). The same conditions were used in the following studies.

Dexamethasone treatment. $300-\mathrm{g}$ male rats were treated with $1.5 \mathrm{mg} / \mathrm{kg}$ dexamethasone phosphate in $0.5 \mathrm{ml} 0.15 \mathrm{M} \mathrm{NaCl}$ i.p. Five rats were given one injection and sacrificed $24 \mathrm{~h}$ later. Five rats were given five injections at 24 -h intervals and sacrificed $24 \mathrm{~h}$ after the last injection. Control rats were given one or five injections of $0.5 \mathrm{ml} 0.15 \mathrm{M} \mathrm{NaCl}$ i.p.

Endotoxin treatment. Seven male rats were injected i.p. with $5 \mathrm{mg} / \mathrm{kg}$ endotoxin (lipopolysaccharide B, Escherichia coli 055: B5, Difco Laboratories, Detroit, Mich.) in $0.5 \mathrm{ml} 0.15$ $\mathrm{M} \mathrm{NaCl}$. Seven control rats were injected with $0.5 \mathrm{ml} 0.15 \mathrm{M}$ $\mathrm{NaCl}$ i.p. The rats were sacrificed $15 \mathrm{~h}$ after injection in one experiment and $24 \mathrm{~h}$ after injection in another and had access to food and water during that interval. 3 out of 14 rats injected with endotoxin died.

Statistical methods. Mean values from experimental groups were compared to controls using Student's $t$ test for unpaired data. In the in vivo experiments the results of the liver homogenate incubations are given as percent of the mean value from control animals to allow results from different groups of rats and data from different assays to be compared.

\section{RESULTS}

Time-course of the reactions. Fig. 1 shows the production of $\mathrm{T}_{3}$ as a function of time when varying 


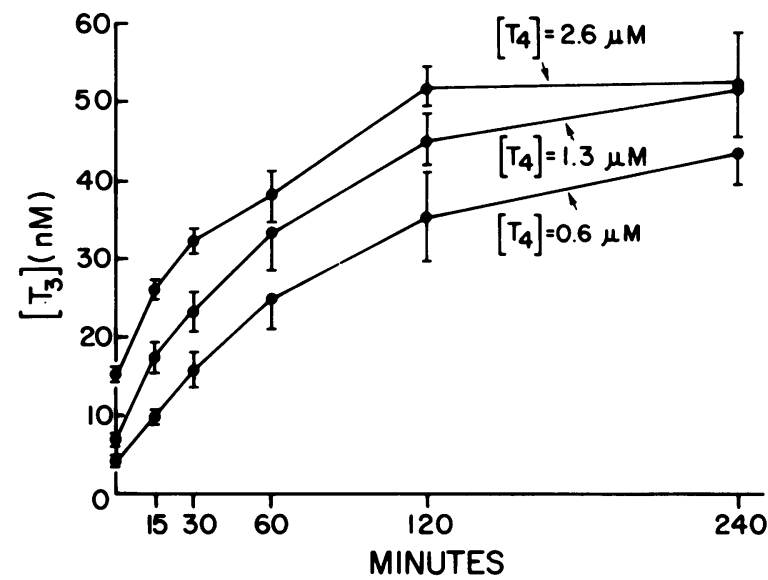

Figure $1 \mathrm{~T}_{3}$ concentrations $\pm \mathrm{SE}$ in liver homogenate during 240-min incubations with initial $\mathrm{T}_{4}$ concentrations of $0.6,1.3$, and $2.6 \mu \mathrm{M}$. No $\mathrm{T}_{3}$ was added.

amounts of $\mathrm{T}_{4}(0.6-2.6 \mu \mathrm{M})$ were incubated with liver homogenate. With each dose of $\mathrm{T}_{4}$ the rate of $\mathrm{T}_{3}$ production declined after $30-60 \mathrm{~min}$. With initial $\mathrm{T}_{4}$ concentrations of $0.65,1.3$, and $2.6 \mu \mathrm{mol} / \mathrm{liter}$, the net production of $\mathrm{T}_{3}$ in $240 \mathrm{~min}$ was $22.1,27.7$, and $23.2 \mathrm{nmol} /$ liter, representing conversion of $3.4,2.1$, and $0.9 \%$, respectively, of the initial $\mathrm{T}_{4}$ added. No decline in directly measured $T_{4}$ concentrations was detectable in this period. With no added $T_{4}$, there was no increase in homogenate $T_{3}$ concentration over $120 \mathrm{~min}$. No measurable production of $\mathrm{rT}_{3}$ from $\mathrm{T}_{4}$ occurred.
The rate of degradation of $\mathrm{rT}_{3}$ (Fig. 2A) diminished after 2-3 min. At low initial concentrations (15.4 and $38.5 \mathrm{nM}$ ), most of the $\mathrm{rT}_{3}$ disappeared in $10 \mathrm{~min}$. At higher $\mathrm{rT}_{3}$ concentrations (77 and $154 \mathrm{nM}$ ), degradation could be measured for up to $60 \mathrm{~min}$ (data not shown). When $T_{4}$ and $T_{3}$ were incubated at similar low initial concentrations, there was no detectable degradation of either in 120 min as shown in Figs. 2B and 2C.

Reaction conditions. No significant differences were found in the rate of $\mathrm{T}_{3}$ production from $\mathrm{T}_{4}$ or $\mathrm{rT}_{3}$ degradation when portions of the same livers were homogenized in $0.05 \mathrm{M}$ Tris, $0.05 \mathrm{M}$ Tris $+0.25 \mathrm{M}$ sucrose, $0.05 \mathrm{M}$ Tris + 0.25 M glucose, $0.05 \mathrm{M} \mathrm{Na}_{2} \mathrm{HPO}_{4}$ $-0.15 \mathrm{M} \mathrm{NaCl}$, or $0.05 \mathrm{M} \mathrm{Na}_{2} \mathrm{HPO}_{4}-0.15 \mathrm{NaCl}+0.25$ $\mathrm{M}$ glucose, all at a buffer $\mathrm{pH}$ of 7.4.

The rate of $\mathrm{T}_{4}$ to $\mathrm{T}_{3}$ conversion at $22^{\circ} \mathrm{C}$ was $32 \%$ of the rate at $37^{\circ} \mathrm{C}$; at $4^{\circ} \mathrm{C}$ it was $10 \%$ of the $37^{\circ} \mathrm{C}$ rate. The rate of $\mathrm{rT}_{3}$ degradation at $22^{\circ} \mathrm{C}$ was $28 \%$, and the rate at $4^{\circ} \mathrm{C}$ was $12 \%$ of the rate of degradation at $37^{\circ} \mathrm{C}$. Heating the homogenate at $56^{\circ} \mathrm{C}$ for $30 \mathrm{~min}$ before incubation at $37^{\circ} \mathrm{C}$ completely abolished both activities.

The $\mathrm{pH}$ of the homogenates was initially $0.2 \mathrm{pH}$ units less than that of the buffer, and it decreased by $0.1-0.2$ $\mathrm{pH}$ units during the course of a 2 -h incubation. There was no variation in reaction rate for $T_{4}$ to $T_{3}$ conversion or $\mathrm{rT}_{3}$ degradation using $0.05 \mathrm{M}$ Tris between $\mathrm{pH} 6.8$ and 7.6 (measured at zero time directly in the homogenate). At $\mathrm{pH} 8.1$ and $\mathrm{pH}$ 6.6, the degradation of $\mathrm{rT}_{3}$ was $50 \%$ of the rate at $\mathrm{pH} 7.2-7.6$. A homogenate $\mathrm{pH}$ of 7.4 ( $\mathrm{pH}$ of the Tris buffer being 7.6) was used in all other experiments.

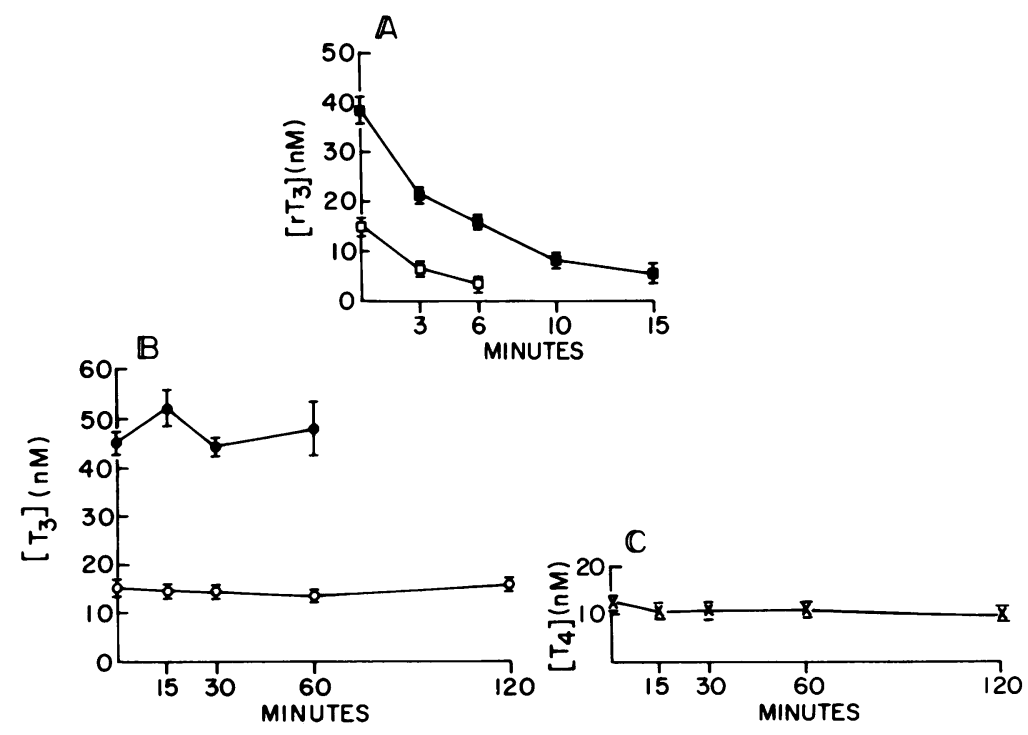

Figure 2 (A) $\mathrm{rT}_{3}$ concentrations $\pm \mathrm{SE}$ in liver homogenate during 15-min incubations with initial $\mathrm{rT}_{3}$ concentrations of $15.4(\square)$ and $30.8(\square) \mathrm{nM}$. (B) $\mathrm{T}_{3}$ concentrations $\pm \mathrm{SE}$ in liver homogenate during 60- and 120-min incubations with initial $\mathrm{T}_{3}$ concentrations of $15.4(O)$ and 45 (O) $\mathrm{nM}$. (C) $\mathrm{T}_{4}$ concentrations $\pm \mathrm{SE}$ in liver homogenate during 120 -min incubations with an initial $\mathrm{T}_{4}$ concentration of $12.9 \mathrm{nM}(\mathrm{x})$. 


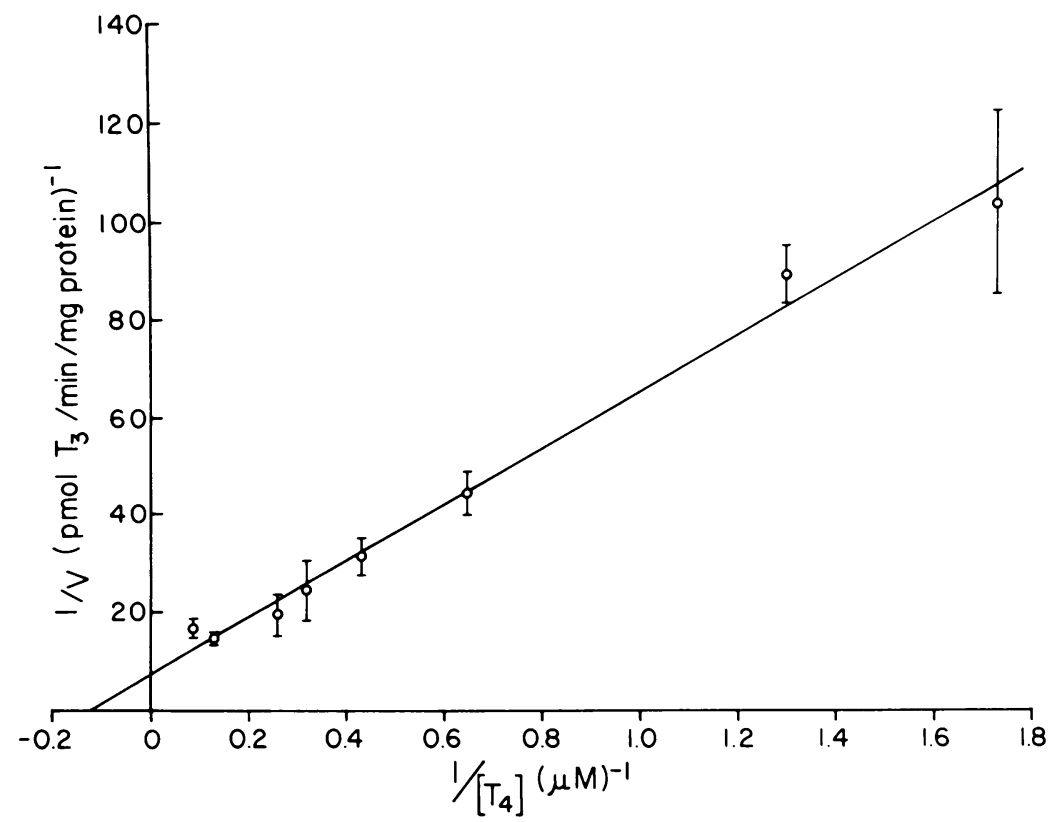

FIgure 3 Lineweaver-Burk plot of $\mathrm{T}_{4}$ to $\mathrm{T}_{3}$ conversion. Values shown are mean $\pm \mathrm{SE}$ results from four incubation mixtures.

Reaction kinetics. Fig. 3 shows a Lineweaver-Burk plot for the conversion of $\mathrm{T}_{4}$ to $\mathrm{T}_{3}$. Values for $V$ were calculated in picomoles $T_{3}$ /minute per milligram protein using the 0 - and 15 -min time points, i.e. during the period when the reaction rate was constant. The line of best fit using the least squares method yielded a $K_{m}$ for $\mathrm{T}_{4}$ of $7.7 \mu \mathrm{M}$ and a $V_{\max }$ of $0.13 \mathrm{pmol} \mathrm{T}_{3} / \mathrm{min}$ per $\mathrm{mg}$ protein. With an initial $\mathrm{T}_{4}$ concentration of $1.3 \mu \mathrm{M}$, the concentration used in most of the subsequent studies, the mean reaction rate was $0.025 \pm 0.003$ pmol SE $\mathrm{T}_{3}$ / min per mg protein. Fig. 4 shows a Lineweaver-Burk plot for $\mathrm{rT}_{3}$ degradation. $V$ was calculated in picomoles $\mathrm{rT}_{3} /$ minute per milligram protein from the 7 -s, 0.5 - and 1-min time points. The least squares line of best fit yielded a $K_{m}$ for $\mathrm{rT}_{3}$ of $7.5 \mathrm{nM}$ and a $V_{\max }$ of $0.36 \mathrm{pmol}$ $\mathrm{rT}_{3} /$ min per mg protein. The difference in the $K_{m}$ values for $\mathrm{T}_{4}$ and $\mathrm{rT}_{3}$ implies that, if there is a single $5^{\prime}$-deiodinase, its affinity for $\mathrm{rT}_{3}$ is about 1,000 -fold greater than that for $\mathrm{T}_{4}$.

Interactions of iodothyronines. Table I shows that conversion of $T_{4}$ to $T_{3}$ was not inhibited by addition of $T_{3}$ or of 3,5- $T_{2}$, but was inhibited in a dose-dependent manner by the addition of $\mathrm{rT}_{3}$ and $3,3^{\prime}-\mathrm{T}_{2} \cdot \mathrm{rT}_{3}$ was $\cong$ four times as potent an inhibitor as $3,3^{\prime}-\mathrm{T}_{2}$ on a molar basis. A Dixon plot of $\mathrm{rT}_{3}$ inhibition of $\mathrm{T}_{4}$ to $\mathrm{T}_{3}$ conversion is shown in Fig. 5. As mentioned above, the mean of the initial and final $\mathrm{rT}_{3}$ concentrations was used in the calculations. Straight lines were fitted to the points shown by the least squares method. The intersection of the lines above the $\mathrm{x}$ axis, and the reasonable fit of the points to straight lines, suggest that $\mathrm{rT}_{3}$ is a competitive inhibitor of $\mathrm{T}_{4}$ to $\mathrm{T}_{3}$ conversion, with a $K_{i}$ of $4.5 \mathrm{nM}$, close to the $K_{m}$ of $\mathrm{rT}_{3}(7.5 \mathrm{nM})$ in the $\mathrm{rT}_{3}$ degradation reaction.

Table II shows that $\mathrm{T}_{4}$ inhibited $\mathrm{rT}_{3}$ degradation in a dose-dependent fashion, but that the other iodothyronines did not. In particular, $3,3^{\prime}-\mathrm{T}_{2}$ at a $0.15 \mu \mathrm{M}$ concentration had no effect in inhibiting $\mathrm{rT}_{3}$ degradation, whereas the same $3,3^{\prime}-\mathrm{T}_{2}$ concentration substantially inhibited $T_{4}$ to $T_{3}$ conversion (cf. Table $I$ ). Fig. 6 is a

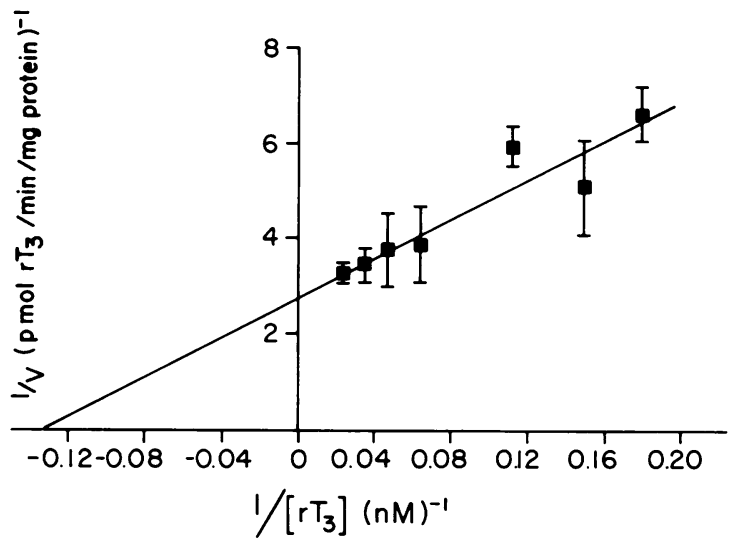

Figure 4 Lineweaver-Burk plot of $\mathrm{rT}_{3}$ degradation. Each point represents the mean of five incubations of 1 min duration. The $y$ axis shows $1 / v \pm S E$. The $x$ axis shows the means of the reciprocals of the average $\left[\mathrm{rT}_{3}\right]$ (1/2 [added $\mathrm{rT}_{3}+$ measured $\mathrm{rT}_{3}$ after $\left.1 \mathrm{~min}\right]$ ) during the incubation. The standard errors of $1 /\left[\mathrm{rT}_{3}\right]$ (not shown) ranged from 0.001 to $0.005 \mathrm{nM}^{-1}$. 
TABLE I

Inhibition of $T_{4}$ to $T_{3}$ Conversion by Iodothyronines

\begin{tabular}{lcccc}
\hline $\begin{array}{l}\text { Iodothy- } \\
\text { ronine }\end{array}$ & $\begin{array}{c}\text { Concen- } \\
\text { tration }\end{array}$ & $\begin{array}{c}\text { (Inhibitor) } \\
\text { (Substrate) }\end{array}$ & $\begin{array}{c}\mathrm{T}_{3} \text { production } \\
\text { rate }\end{array}$ & $P$ \\
\hline & $\mu M$ & & $\begin{array}{c}\% \text { control } \\
\text { mean } \pm S E\end{array}$ & \\
& & & $111 \pm 19$ & $\mathrm{NS}$ \\
$\mathrm{T}_{3}$ & 0.120 & 0.092 & & $<0.001$ \\
$\mathrm{rT}_{3}$ & 0.019 & 0.015 & $31 \pm 8$ & $<0.001$ \\
& 0.039 & 0.029 & $3 \pm 1$ & $<0.001$ \\
& 0.077 & 0.059 & $2 \pm 1$ & $<0.001$ \\
$3,3^{\prime}-\mathrm{T}_{2}$ & 0.038 & 0.029 & $42 \pm 3$ & $<0.001$ \\
& 0.076 & 0.059 & $34 \pm 5$ & $<0.001$ \\
& 0.150 & 0.117 & $16 \pm 5$ & $\mathrm{NS}$ \\
$3,5-\mathrm{T}_{2}$ & 0.150 & 0.117 & $87 \pm 6$ & \\
\hline
\end{tabular}

Initial $\mathrm{T}_{4}$ concentration was $1.3 \mu \mathrm{M}$. Three to five identical incubations were used for each inhibitor concentration and compared to an equal number of simultaneous control incubations with $\mathrm{T}_{4}$ alone.

Dixon plot of $\mathrm{T}_{4}$ inhibition of $\mathrm{rT}_{3}$ degradation. These data suggest that $T_{4}$ is a competitive inhibitor of $\mathrm{rT}_{3}$ degradation, with a $K_{i}$ of $10.2 \mu \mathrm{M}$, quite similar to the $K_{m}$ of $\mathrm{T}_{4}(7.7 \mu \mathrm{M})$ in the $\mathrm{T}_{4}$ to $\mathrm{T}_{3}$ conversion reaction.

Other inhibitors. Propylthiouracil (PTU) inhibited both $\mathrm{T}_{4}$ to $\mathrm{T}_{3}$ conversion and $\mathrm{rT}_{3}$ degradation (Table III). The PTU dose-response relationships were similar for both reactions, but inhibition was

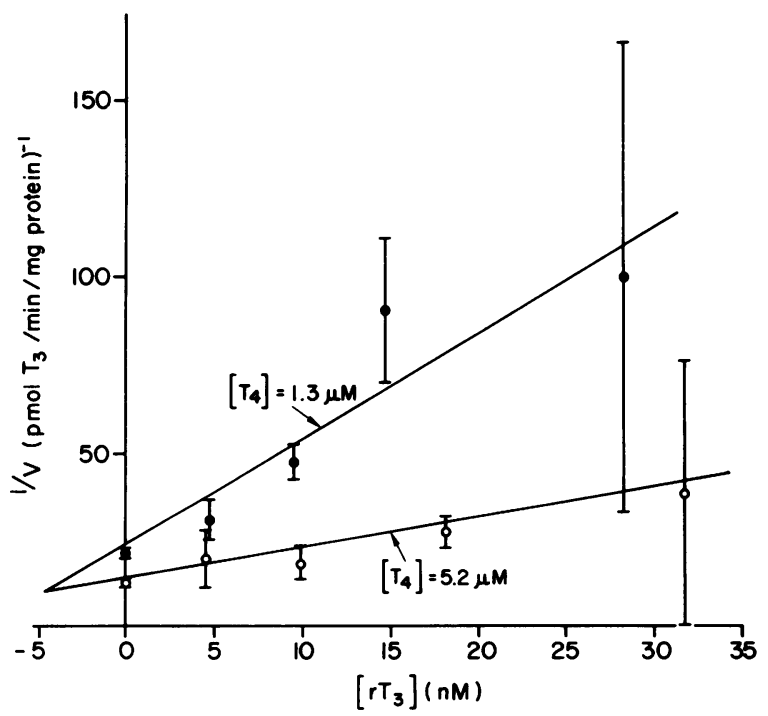

Figure 5 Dixon plot of $\mathrm{rT}_{3}$ inhibition of $\mathrm{T}_{4}$ to $\mathrm{T}_{3}$ conversion. Each point represents the mean of five incubations of 5 min duration. The $y$ axis shows $1 / v \pm S E$. The $x$ axis shows the average $\left[\mathrm{rT}_{3}\right]$ ( $1 / 2$ [added $\mathrm{rT}_{3}+$ measured $\mathrm{rT}_{3}$ after $5 \mathrm{~min}]$ ) during the incubation. The standard errors of $\left[\mathrm{rT}_{3}\right]$ (not shown) ranged from 0.2 to $1.7 \mathrm{nM}$.
TABLE II

Inhibition of $r T_{3}$ Degradation by Iodothyronines

\begin{tabular}{lcccc}
\hline $\begin{array}{c}\text { Iodothy- } \\
\text { ronine }\end{array}$ & $\begin{array}{c}\text { Concen- } \\
\text { tration }\end{array}$ & $\begin{array}{c}\text { (Inhibitor) } \\
\text { (Substrate) }\end{array}$ & $\begin{array}{c}\mathrm{rT}_{3} \text { degradation } \\
\text { rate }\end{array}$ & $P$ \\
\hline & $\mu M$ & & $\begin{array}{c}\% \text { control } \\
\text { mean } \pm S E\end{array}$ & \\
& & & $53 \pm 5$ & $<0.01$ \\
$\mathrm{~T}_{4}$ & 5.9 & 980 & $54 \pm 9$ & $<0.01$ \\
& 12 & 1940 & $44 \pm 9$ & $<0.01$ \\
& 24 & 3870 & $\mathrm{NS}$ \\
$\mathrm{T}_{3}$ & 15 & 1000 & $77 \pm 4$ & $\mathrm{NS}$ \\
$3,3^{\prime}-\mathrm{T}_{2}$ & 0.15 & 10 & $91 \pm 4$ & $\mathrm{NS}$ \\
$3,5-\mathrm{T}_{2}$ & 0.15 & 10 & $113 \pm 9$ & $\mathrm{NS}$ \\
\hline
\end{tabular}

Initial $\mathrm{rT}_{3}$ concentrations in the $\mathrm{T}_{4}$ inhibition experiments were $6.2 \mathrm{nM}$, and they were $15 \mathrm{nM}$ in the other experiments. Four to five identical incubations were used for each inhibitor concentration and compared to an equal number of control incubations with $\mathrm{rT}_{3}$ alone.

incomplete even with very large quantities of PTU. Increasing the concentration of PTU from $1.76 \mu \mathrm{M}$, the lowest concentration at which inhibition was consistently observed, to $59 \mu \mathrm{M}$, a 33-fold increase, resulted in a decrease in the rate of $\mathrm{T}_{3}$ production from $\mathrm{T}_{4}$ from 70 to $46 \%$ of control, and a decrease in the rate of $\mathrm{rT}_{3}$ degradation from 77 to $26 \%$ of control. A further six-fold increase in PTU concentration had little further effect. The hyperbolic shape of the Dixon plot (Fig. 7) of the PTU inhibition of $T_{4}$ to $T_{3}$ conversion suggests that PTU alters the affinity of the enzyme for $\mathrm{T}_{4}$, i.e. is an allosteric inhibitor, rather

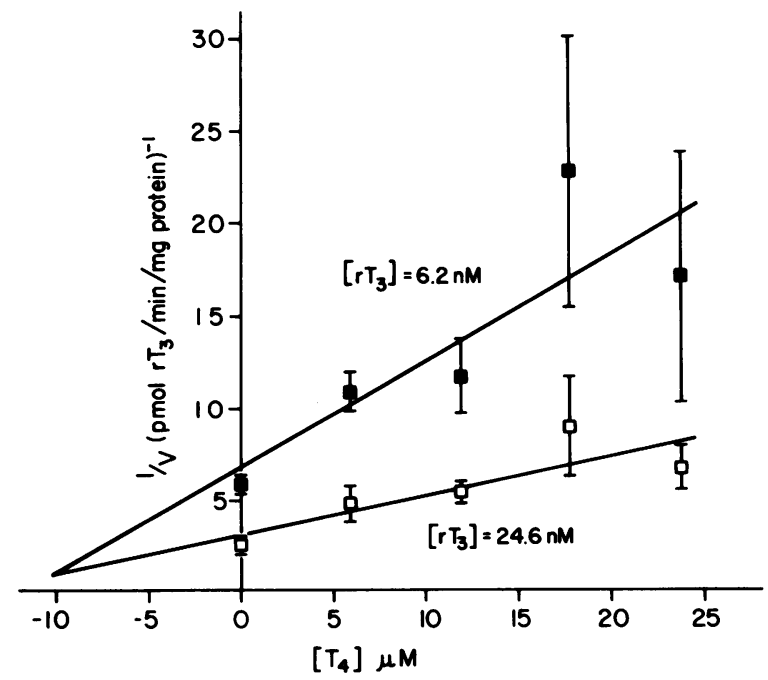

Figure 6 Dixon plot of $\mathrm{T}_{4}$ inhibition of $\mathrm{rT}_{3}$ degradation. Each point represents the mean of five incubations of $1 \mathrm{~min}$ duration. The $y$ axis shows $1 / v \pm S E$. The $x$ axis shows the concentration of added $\mathrm{T}_{4}$. 
TABLE III

Inhibition of $T_{4}$ to $T_{3}$ Conversion and $r T_{3}$ Degradation in Rat Liver Homogenate by Propylthiouracil

\begin{tabular}{|c|c|c|c|c|c|c|}
\hline $\begin{array}{c}\text { PTU } \\
\text { concen- } \\
\text { tration }\end{array}$ & $n$ & $\begin{array}{c}T_{4} \text { to } T_{3} \\
\text { conversion }\end{array}$ & $P^{*}$ & $n$ & $\begin{array}{c}\mathrm{rT}_{3} \\
\text { degradation }\end{array}$ & $P^{*}$ \\
\hline$\mu M$ & & $\begin{array}{c}\% \text { of } \\
\text { control } \downarrow\end{array}$ & & & $\begin{array}{c}\% \text { of } \\
\text { control } \$\end{array}$ & \\
\hline 1.76 & 5 & $70 \pm 2$ & $<0.001$ & 5 & $77 \pm 16$ & NS \\
\hline 5.9 & 5 & $57 \pm 3$ & $<0.001$ & 11 & $52 \pm 11$ & $<0.001$ \\
\hline 59 & 5 & $46 \pm 3$ & $<0.001$ & 6 & $26 \pm 6$ & $<0.001$ \\
\hline 352 & 5 & $49 \pm 8$ & $<0.001$ & 3 & $34 \pm 2$ & $<0.001$ \\
\hline
\end{tabular}

* Incubations with PTU compared to an equal number $(n)$ of simultaneous control incubations. The initial $\mathrm{T}_{4}$ and $\mathrm{rT}_{3}$ concentrations were $1.3 \mu \mathrm{M}$ and $1.54 \mathrm{nM}$, respectively. $\mathrm{T}_{4}$ incubations were carried out for $15 \mathrm{~min}$ and $\mathrm{rT}_{3}$ incubations for $2 \mathrm{~min}$.

$\$$ Mean \pm SE.

than acting at the catalytic site. There was no measurable production of $\mathrm{rT}_{3}$ from $\mathrm{T}_{4}$ when $\mathrm{rT}_{3}$ degradation was (partially) inhibited by PTU.

Table IV shows that 2,4-dinitrophenol and iopanoic acid were effective inhibitors both of $\mathrm{T}_{4}$ to $\mathrm{T}_{3}$ conversion and $\mathrm{rT}_{3}$ degradation. There was no $\mathrm{rT}_{3}$ production from $\mathrm{T}_{4}$ when $\mathrm{rT}_{3}$ degradation was almost completely inhibited by $10 \mu \mathrm{M}$ iopanoic acid. Sodium diatrizoate, an iodinated contrast agent like iopanoic acid, had a modest inhibitory effect of $\mathrm{rT}_{3}$ degradation. It appeared to inhibit $T_{4}$ to $T_{3}$ conversion to the same degree, but this inhibition was not statistically significant. Other agents tested and found to have neither stimulatory nor inhibitory effects on $T_{4}$ to $T_{3}$ conversion or $\mathrm{rT}_{3}$ degradation included $13 \mu \mathrm{M}$ dexamethasone, $8 \mu \mathrm{M}$ NaI, $1 \mu \mathrm{M} \alpha$-methylparatyrosine,

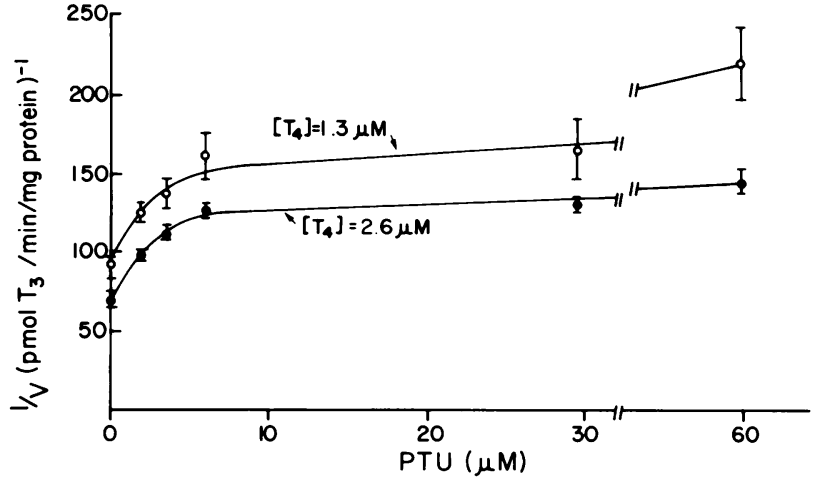

Figure 7 Dixon plot of inhibition of $T_{4}$ to $T_{3}$ conversion by PTU with initial $T_{4}$ concentrations of $1.3(O)$ and $2.6(0)$ $\mu \mathrm{M}$. Values shown are the means $\pm \mathrm{SE}$ from four or five incubation mixtures.

$89 \mu \mathrm{M}$ 1-methyl-2-mercaptoimidazole, $1 \mathrm{mM} \mathrm{FeCl}$, $1 \mathrm{mM} \mathrm{FeCl}, 1 \mathrm{mM}$ reduced glutathione, $1 \mathrm{mM}$

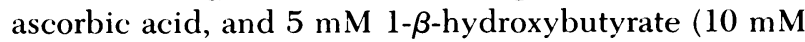
$\mathrm{Na}$ salt of d,1- $\beta$-hydroxybutyrate). $1.5 \mathrm{mM}$ oleic acid resulted in a rate of $T_{4}$ to $T_{3}$ conversion of $135 \pm 6 \%$ $\mathrm{SE}$ of control $(P<0.05)$, but with $2.5 \mathrm{mM}$ oleic acid concentration the rate was not different from control $(98 \pm 19 \%) .1 .5 \mathrm{mM}$ oleic acid did not alter $\mathrm{rT}_{3}$ degradation.

Other tissues. Kidney homogenate was as active as liver in producing $T_{3}$ from $T_{4}$. At an initial $T_{4}$ concentration of $1.3 \mu \mathrm{M}$, the rate of $\mathrm{T}_{3}$ production was $0.021 \pm 0.004 \mathrm{pmol} / \mathrm{min}$ per $\mathrm{mg}$ protein, compared to $0.025 \pm 0.003 \mathrm{pmol} / \mathrm{min}$ per $\mathrm{mg}$ protein for liver homogenate. PTU at a concentration of $3.5 \mu \mathrm{M}$ in kidney homogenate reduced $\mathrm{T}_{3}$ production to $80 \pm 3 \% \mathrm{SE}$ of control, at $7 \mu \mathrm{M}$ the rate was $43 \pm 8 \%$ of control and at $59 \mu \mathrm{M}$ PTU, $45 \pm 15 \%$ of control, a pattern

TABLE IV

Inhibition of $T_{4}$ to $T_{3}$ Conversion and $r T_{3}$ Degradation by 2,4-Dinitrophenol, Sodium Diatrizoate, and Iopanoic Acid

\begin{tabular}{lccccccc}
\hline \multicolumn{1}{c}{ Inhibitor } & $\begin{array}{c}\text { Concen- } \\
\text { tration }\end{array}$ & $n$ & $\begin{array}{c}\mathrm{T}_{4} \text { to } \mathrm{T}_{3} \\
\text { conversion }\end{array}$ & $P^{*}$ & $n$ & $\begin{array}{c}\mathrm{rT}_{3} \\
\text { degradation }\end{array}$ & $P^{*}$ \\
\hline & & \multicolumn{3}{c}{$\%$ control $\mathrm{f}$} \\
2,4-Dinitrophenol, $m M$ & 1 & 5 & $48 \pm 16$ & $<0.05$ & 5 & $21 \pm 2$ & $<0.001$ \\
2,4-Dinitrophenol, $m M$ & 2 & 5 & $18 \pm 8$ & $<0.001$ & 5 & $6 \pm 2$ & $<0.001$ \\
Sodium diatrizoate, $m M$ & 7.8 & 5 & $84 \pm 9$ & $\mathrm{NS}$ & 5 & $81 \pm 3$ & $<0.01$ \\
Iopanoic acid, $\mu M$ & 0.1 & 3 & $58 \pm 5$ & $<0.01$ & 3 & $73 \pm 7$ & $<0.05$ \\
Iopanoic acid, $\mu M$ & 1 & 3 & $10 \pm 2$ & $<0.001$ & 3 & $43 \pm 6$ & $<0.01$ \\
Iopanoic acid, $\mu M$ & 10 & 3 & $8 \pm 3$ & $<0.001$ & 3 & $19 \pm 4$ & $<0.001$ \\
\hline
\end{tabular}

* Incubations with inhibitor compared to an equal number $(n)$ of simultaneous control incubations. The initial $\mathrm{T}_{4}$ and $\mathrm{rT}_{3}$ concentrations were $1.3 \mu \mathrm{M}$ and $1.54 \mathrm{nM}$, respectively. Incubations were carried out for $15 \mathrm{~min}\left(\mathrm{~T}_{4}\right)$ and 1 and $2 \mathrm{~min}\left(\mathrm{rT}_{3}\right)$.

$\uparrow$ Mean \pm SE. 
quite like that observed in liver homogenate (cf. Table I). Kidney homogenate was likewise as active as liver homogenate in degrading $\mathrm{rT}_{3}$; at an initial $\mathrm{rT}_{3}$ concentration of $15.4 \mathrm{nM}$, the rate of disappearance of $\mathrm{rT}_{3}$ was $0.083 \pm 0.011 \mathrm{pmol} / \mathrm{min}$ per $\mathrm{mg}$ protein in kidney homogenate, compared to $0.070 \pm 0.011 \mathrm{pmol} /$ min per $\mathrm{mg}$ protein in liver homogenate. There was no measurable production of $\mathrm{T}_{3}$ or $\mathrm{rT}_{3}(<0.5 \mathrm{fmol} /$ min per $\mathrm{mg}$ protein) from $\mathrm{T}_{4}$ or destruction of $\mathrm{rT}_{3}$ $(<1.2 \mathrm{fmol} / \mathrm{min}$ per $\mathrm{mg}$ protein) in homogenates of brain, lung, heart muscle, spleen, or intestine.

\section{In vivo studies}

Fasting experiments. Results of these studies are shown in Fig. 8. The rate of $\mathrm{T}_{4}$ to $\mathrm{T}_{3}$ conversion in liver homogenate (initial $\mathrm{T}_{4}$ concentration $1.3 \mu \mathrm{M}$ ) was not significantly different from control at $24 \mathrm{~h}$. It fell to $57 \pm 8 \%$ of control after $48 \mathrm{~h}(P<0.02)$ and remained at this level subsequently. The rates at 48,72 , and $96 \mathrm{~h}$ were not significantly different from one another. After refeeding there was slow return of $\mathrm{T}_{4}$ to $\mathrm{T}_{3}$ conversion by the liver homogenate to the control rate; there was still significant impairment of $T_{4}$ to
$\mathrm{T}_{3}$ conversion after $96 \mathrm{~h}$ of refeeding $(68 \pm 4 \%$ of control, $P<0.05$ ), but no significant difference from control after $144 \mathrm{~h}$ (6 days) of refeeding.

The degradation rate of $\mathrm{rT}_{3}$ in the liver homogenate was normal after $24 \mathrm{~h}$ of fasting. It was reduced to $82 \pm 8 \%$ of control $(P<0.05)$ after $48 \mathrm{~h}$, and was further reduced after 72 and $96 \mathrm{~h}(P<0.01)$. After refeeding, the $\mathrm{rT}_{3}$ degradation rate returned to normal by $24 \mathrm{~h}$. There was no change in the protein content of the liver homogenates from fasting animals.

The mean serum $\mathrm{T}_{4}$ concentration after $24 \mathrm{~h}$ of fasting was slightly but significantly lower $(P<0.02)$ than the control value. It fell further after $48 \mathrm{~h}(P$ $<0.001)$ and remained in the same range thereafter. During refeeding, there was a progressive increase in the mean serum $\mathrm{T}_{4}$ concentration; it was normal after $72 \mathrm{~h}$ of refeeding. The mean serum $\mathrm{T}_{3}$ concentration after $24 \mathrm{~h}$ of fasting was significantly lower than control $(P<0.01)$, was lower still after $48 \mathrm{~h}$ and remained in the same range thereafter. In the fasted rats, the mean $\mathrm{T}_{3}$-charcoal uptakes were $38 \%$ at $24 \mathrm{~h}$, $36 \%$ at $48 \mathrm{~h}$, and $35 \%$ at $72 \mathrm{~h}$, not significantly different from control (39\%). After $96 \mathrm{~h}$ the $\mathrm{T}_{3}$ charcoal uptake decreased to $31 \%, P<0.01$. These data suggest
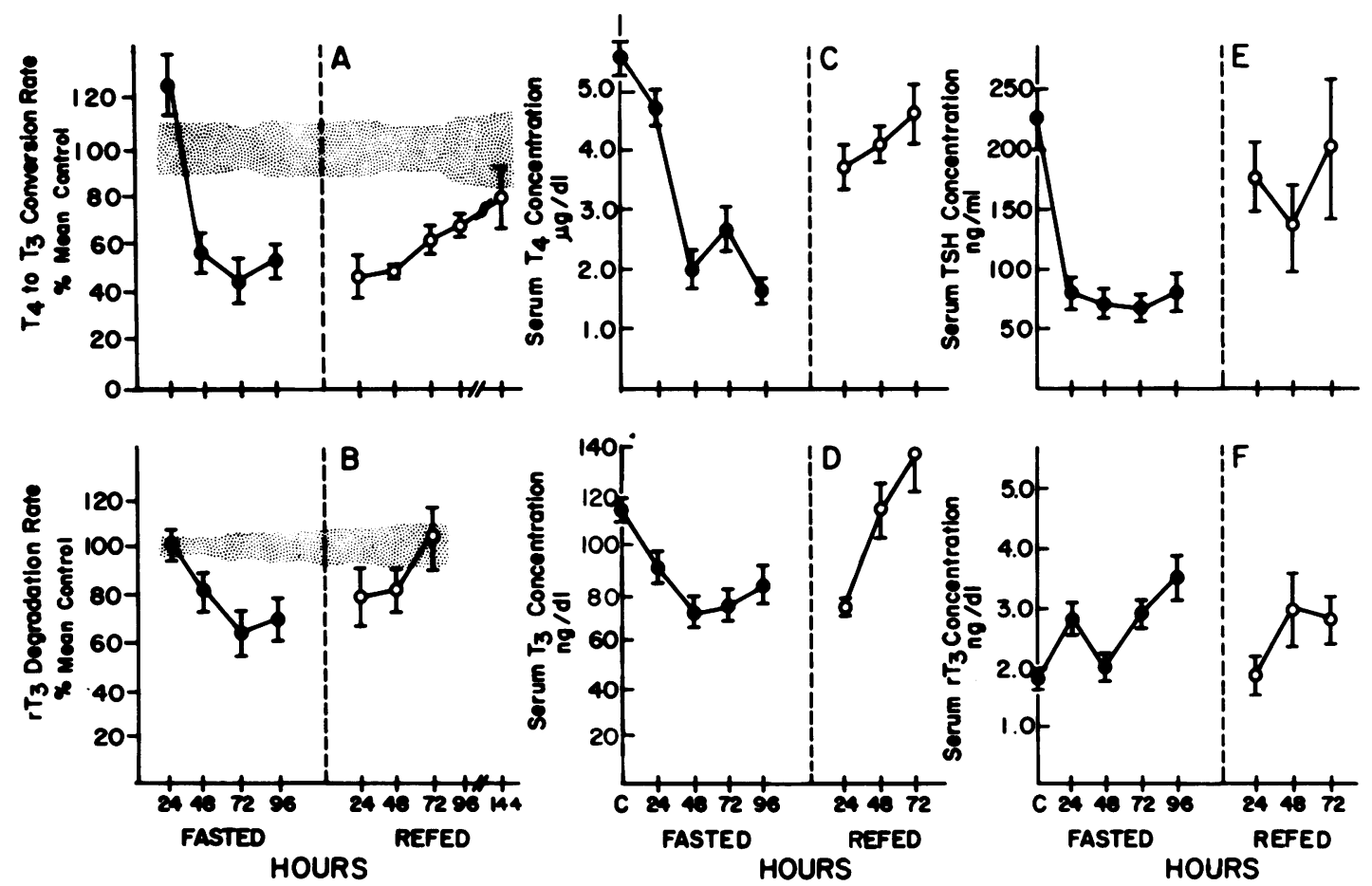

FIgURE 8 Liver homogenate $\mathrm{T}_{4}$ to $\mathrm{T}_{3}$ conversion and $\mathrm{rT}_{3}$ degradation, serum $\mathrm{TSH}$, and thyroid hormone concentrations in rats during starvation $(O)$ and refeeding $(O)$. The refeeding experiments were done in animals previously fasted for $72 \mathrm{~h}$. Data from liver homogenate incubations are expressed as mean $\pm \mathrm{SE}$ values compared to simultaneously studied fed controls. Serum hormone results are mean $\pm S E$ concentrations. Each point represents data from 5 to 15 rats. The shaded area in panels $A$ and $B$ represents $\pm S E$ for the control rats at each time point. 
that the serum free $T_{3}$ parallels the total $T_{3}$, and that fasting truly represents a low $\mathrm{T}_{3}$ state in the rat.

Serum $\mathrm{rT}_{3}$ concentrations, corrected for $\mathrm{T}_{4}$ crossreactivity (see above), showed no consistent change, although the mean values on several days during fasting and refeeding were higher than control. Because these values are so low and involve a substantial correction for $\mathrm{T}_{4}$ cross-reactivity, they must be interpreted with caution. With that reservation, there was no fall in serum $\mathrm{rT}_{3}$ despite a $60 \%$ decrease in the mean serum $\mathrm{T}_{4}$. Serum TSH concentrations fell significantly after $24 \mathrm{~h}$ of fasting $(P$ $<0.001)$ and remained at the same level thereafter. Serum TSH concentrations returned to normal after $72 \mathrm{~h}$ of refeeding.

Dexamethasone. Results are shown in Fig. 9. The liver homogenates from rats treated with a single dose of dexamethasone did not have significantly lower mean rates of $T_{4}$ to $T_{3}$ conversion and $\mathrm{rT}_{3}$ degradation than the controls. The mean serum concentrations of $\mathrm{T}_{4}, \mathrm{~T}_{3}$, and TSH were also not significantly different in the treated animals and the controls. The corrected mean serum $\mathrm{rT}_{3}$ concentration, $3.5 \pm 0.4 \mathrm{ng} / \mathrm{dl}$, was significantly greater than the mean control value of $1.1 \pm 0.3 \mathrm{ng} / \mathrm{dl}, P<0.01$.

In the animals given daily injections of dexamethasone for 5 days, the mean rate of $T_{4}$ to $T_{3}$ conversion in the liver homogenates was significantly diminished to $44 \pm 4 \%$ of control, $P<0.05$, and the rate of $\mathrm{rT}_{3}$ degradation was also significantly diminished to
$35 \pm 6 \%$ of control, $P<0.001$. There was no significant difference in mean serum concentrations of $T_{4}, T_{3}$, and TSH between the treated and the control rats, but the mean corrected serum $\mathrm{rT}_{3}$ concentration was significantly higher in the dexamethasone treated rats, $4.4 \pm 0.2 \mathrm{ng} / \mathrm{dl}$, than in controls, $2.0 \pm 0.3 \mathrm{ng} / \mathrm{dl}$, $P<0.001$.

Endotoxin. There was no significant alteration in the rate of conversion of $\mathrm{T}_{4}$ to $\mathrm{T}_{3}$ or the rate of degradation of $\mathrm{rT}_{3}$ in the liver homogenates from rats treated with endotoxin compared to controls and no change in the serum concentrations of $T_{4}, T_{3}, r_{3}$, and $\mathrm{TSH}$.

\section{DISCUSSION}

Several inferences can be made about the nature of the reactions that were studied. There is little doubt of the enzymatic nature of $T_{4}$ to $T_{3}$ conversion or $\mathrm{rT}_{3}$ degradation in liver and kidney homogenates as described in this paper, although nonenzymatic deiodination of $\mathrm{T}_{4}$ has been described (49). Typical features of enzymatic catalysis demonstrated for these reactions include temperature and $\mathrm{pH}$ dependence, abolition of activity by heating the liver homogenate to $56^{\circ} \mathrm{C}$, and tissue specificity. The similarity of the $K_{m}$ and $K_{i}$ for $\mathrm{T}_{4}$, and the $K_{m}$ and $K_{i}$ for $\mathrm{rT}_{3}$ and the similarity of effects of inhibitors (e.g. PTU and iopanoic acid) suggest, but do not prove, that a single hepatic enzyme catalyzes 5'-mono-deiodination of both

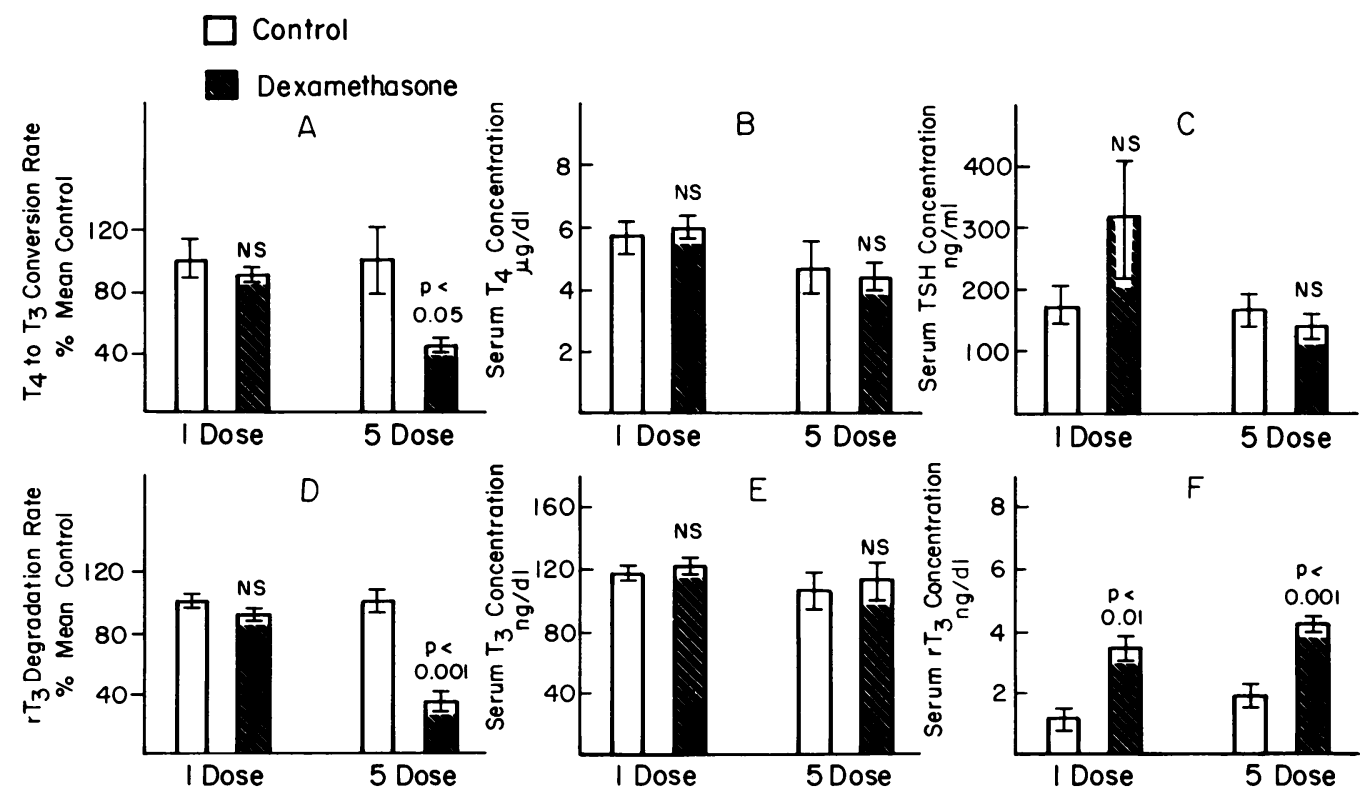

FIgure 9 Liver homogenate $\mathrm{T}_{4}$ to $\mathrm{T}_{3}$ conversion and $\mathrm{rT}_{3}$ degradation and serum $\mathrm{TSH}$ and thyroid hormone concentrations in rats treated with one and five daily doses of dexamethasone ( $1.5 \mathrm{mg} / \mathrm{kg}$ i.p.). Values are mean $\pm \mathrm{SE}$ results from five rats. Open bars represent data from control rats and hatched bars data from dexamethasone-treated rats. 
$\mathrm{T}_{4}$ and $\mathrm{rT}_{3}$. Proof that $\mathrm{rT}_{3}$ was degraded by $5^{\prime}$ deiodination to $3,3^{\prime}-T_{2}$ was not obtained in this study, but Chopra has reported rapid production of $3,3^{\prime}-\mathrm{T}_{2}$ from $\mathrm{rT}_{3}$ and inhibition of this reaction by PTU in a similar liver homogenate system (40). The similarity of the rates of $T_{4}$ to $T_{3}$ conversion in liver and kidney homogenates and of the rates of $\mathrm{rT}_{3}$ degradation in liver and kidney shown above are also in general agreement with the findings of Chopra, who reported that the activities of heart, lung, intestine, spleen, and brain homogenates in deiodinating $\mathrm{T}_{4}$ and $\mathrm{rT}_{3}$ were much less than in liver or kidney homogenates, and that $\mathrm{rT}_{3}$ inhibits hepatic conversion of $\mathrm{T}_{4}$ to $\mathrm{T}_{3}(27)$. This latter phenomenon raises the possibility that $\mathrm{rT}_{3}$ regulates $T_{3}$ production from $T_{4}$ in vivo in patients who have the diverse disorders associated with elevated serum $\mathrm{rT}_{3}$ and decreased $\mathrm{T}_{3}$ concentrations. Thus, the primary disturbance may be a decrease in $\mathrm{rT}_{3}$ degradation. However, it is not possible to make quantitative estimates of in vivo effects from these data, and there is some evidence against such a mechanism because moderate elevations in serum $\mathrm{rT}_{3}$ concentrations in humans after short-term exogenous $\mathrm{rT}_{3}$ administration have no effect on serum $\mathrm{T}_{3}$ concentrations (50).

The decrease in serum $T_{3}$ and increase in serum $\mathrm{rT}_{3}$ concentrations in humans $(14,16,45)$ and decreased total $T_{4}$ to $T_{3}$ conversion in rats $(47,51)$ found after PTU administration in vivo are likely to be caused by decreased hepatic and renal $\mathrm{T}_{3}$ production and decreased hepatic (and probably decreased renal) $\mathrm{rT}_{3}$ degradation caused by the drug. The mechanism of PTU inhibition of $\mathrm{T}_{4}$ to $\mathrm{T}_{3}$ conversion and $\mathrm{rT}_{3}$ degradation suggested by these experiments, allosteric alteration of the enzyme, differs from the mechanism by which PTU inhibits thyroid hormone synthesis in the thyroid. Taurog has shown that both PTU and 1-methyl-2-mercaptoimidazole are metabolized by thyroperoxidase as they inhibit organification of iodide (52). Inasmuch as 1-methyl-2-mercaptoimidazole had no effect in the present system, it is not surprising that the mechanism of PTU inhibition in the liver and kidney differs from its thyroidal mechanism of action. The PTU response characteristics for $\mathrm{T}_{4}$ to $\mathrm{T}_{3}$ conversion are similar to those reported by Visser et al. (26), whose method formed the basis of that used here, but who did not investigate $\mathrm{rT}_{3}$ metabolism.

Iopanoic acid, a widely used oral cholecystographic agent, when administered to humans, causes a reduction in serum $\mathrm{T}_{3}$ concentrations and an increase in serum $\mathrm{T}_{4}, \mathrm{TSH}$, and $\mathrm{rT}_{3}$ concentrations (16). Evidence is presented here that the effects of iopanoic acid may result from inhibition of $T_{3}$ production and $\mathrm{rT}_{3}$ degradation in the liver (and perhaps elsewhere), with a compensatory increase in TSH secretion and a consequent increase in $\mathrm{T}_{4}$ production. It is likely that inhibition by iopanoic acid is a consequence of its molecular structure, and not of iodide derived from it, because diatrizoate, which has an iodide content similar to that of iopanoic acid, is a much less potent inhibitor of $\mathrm{T}_{3}$ production and $\mathrm{rT}_{3}$ degradation, and because iodide itself, in a concentration similar to that present in the contrast dyes, had no effect.

Several experiments were performed to assess whether compounds effective as stimulators or inhibitors of $T_{4}$ or $T_{3}$ metabolism in other in vitro liver systems had effects in this one. A reduction in $\mathrm{T}_{4}$ deiodination in adult rats (53), and prevention of the neonatal increase in serum $\mathrm{T}_{3}$ in sheep (54), have been reported as consequences of in vivo administration of $\alpha$ methylparatyrosine. This drug had no effect on $\mathrm{T}_{4}$ to $\mathrm{T}_{3}$ conversion or $\mathrm{rT}_{3}$ degradation in liver homogenates. Hillier (55) found that 2,4-dinitrophenol inhibited $\mathrm{T}_{4}$ deiodination by isolated perfused liver in a concentration range similar to that found here to inhibit both $T_{4}$ to $T_{3}$ conversion and $\mathrm{rT}_{3}$ degradation in liver homogenate. Nakagawa and Ruegamer (28), using a more dilute liver homogenate, and Stanbury et al. (37), using a liver microsomal preparation, both of whom used tracer techniques, found stimulation of $\mathrm{T}_{4}$ deiodination by ferrous ion and reduced glutathione, neither of which had a measurable effect in the present system. The time-course of deiodination and the stimulatory effects of dialysis and preheating reported by those workers also contrast to the time-course of the reactions and the inhibitory effect of dialysis (data not shown) and preheating found here. The substantial differences in methods used in those studies and the present one prevent direct comparisons and analysis of discrepancies.

Fasting and administration of dexamethasone and endotoxin were tested as models of the disease states in man characterized by altered extrathyroidal thyroid hormone metabolism $(8,10-12,17,18)$. They were not entirely satisfactory models, however, because serum thyroid hormone and TSH concentrations did not always change as they do in humans in similar situations. Endotoxin, in fact, had no effect on any of the measurements.

In the fasted rats there were decreased serum $T_{4}$, $\mathrm{T}_{3}$, and TSH concentrations and decreased hepatic $\mathrm{T}_{4}$ to $\mathrm{T}_{3}$ conversion, whereas, in fasted humans, serum $\mathrm{T}_{4}$ and TSH do not change markedly (17). Other workers have reported that fasted rats have decreased serum TSH (56), lowered serum protein bound iodine (57), and a decrease in the rate of whole-body $\mathrm{T}_{4}$ deiodination (58), and that liver slices from such rats have a reduced conversion rate of $T_{4}$ to $T_{3}(59)$. The fall in serum $T_{3}$ concentrations corresponded most closely in time to the fall in serum TSH concentrations, inasmuch as both fell substantially after 
$24 \mathrm{~h}$ of starvation, whereas the mean serum $\mathrm{T}_{4}$ concentration fell only slightly, and the rate of hepatic $\mathrm{T}_{4}$ to $T_{3}$ conversion did not change. Return of serum $T_{3}$ concentrations to normal with refeeding was also more rapid than recovery of hepatic $T_{4}$ to $T_{3}$ conversion as measured in vitro. Three possible mechanisms may thus contribute to the fall in serum $T_{3}$ in the fasted rat: decreased availability of the precursor, $\mathrm{T}_{4}$, caused, in turn, by decreased TSH stimulation of $\mathrm{T}_{4}$ secretion; decreased thyroidal secretion of $\mathrm{T}_{3}$ itself; and a decreased capacity of the liver to convert $T_{4}$ to $T_{3}$. The present data suggest that all of those mechanisms are operative but do not allow an estimation of their relative importance. The failure of serum $\mathrm{rT}_{3}$ to fall despite a $55 \%$ decrease in $\mathrm{T}_{4}$ is also likely due to a combination of several processes, including reduced hepatic degradation, but kinetic studies would be needed to verify this. The exact events responsible for reduced hepatic activity in metabolizing $\mathrm{T}_{4}$ and $\mathrm{rT}_{3}$ are not clear, but simple enzyme inhibition by two substances, $\beta$ hydroxybutyrate and oleic acid, known to rise during fasting, was not evident when concentrations achieved endogenously were tested in vitro.

A reduction in $T_{3}$ production from $T_{4}$ in rat liver homogenate after in vivo dexamethasone treatment has been reported recently (48); the results given above confirm that finding and extend it to include a reduction in $\mathrm{rT}_{3}$ degradation rate. The lack of fall in serum $\mathrm{T}_{3}$ concentrations is unexplained; it could reflect either dexamethasone-mediated inhibition of $\mathrm{T}_{3}$ degradation or increased $T_{4}$ to $T_{3}$ conversion at other sites. An elevation in serum $\mathrm{rT}_{3}$ concentrations appeared to precede any substantial change in $\mathrm{rT}_{3}$ metabolism by the liver homogenate. As in the case of fasting, the lack of information about $\mathrm{rT}_{3}$ production in the rat makes comments about mechanisms of changes in serum concentrations speculative. These experiments did not show the expected fall in rat serum $\mathrm{TSH}$ and $\mathrm{T}_{4}$ concentrations after dexamethasone treatment reported by several groups of investigators $(60,61)$. The elevation in rat serum $\mathrm{rT}_{3}$ concentrations in $\leq 24 \mathrm{~h}$ and lack of change for several days thereafter is the same pattern seen in humans given pharmacological doses of dexamethasone $(11,12)$. Whether dexamethasone was ineffective in vitro because of limited exposure of liver tissue to it or because the hepatic effect is a result of an extrahepatic steroid action is not known.

The parallel alterations in hepatic $T_{4}$ to $T_{3}$ conversion and $\mathrm{rT}_{3}$ degradation in the in vivo experiments provide further evidence, in addition to the in vitro kinetic and inhibitor data, that both processes are catalyzed by the same enzyme. These results are consistent with the changes generally observed in various states in humans, namely decreased serum $\mathrm{T}_{3}$ and elevated $\mathrm{rT}_{3}$ concentrations $(4,7,10,12,15,16$,
$18,21,45)$. Moreover, decreases in both $T_{4}$ to $T_{3}$ conversion and $\mathrm{rT}_{3}$ degradation rates in patients with cirrhosis were reported by Chopra (4). Other observations, however, are not in accord with this hypothesis. For example, low serum $\mathrm{T}_{3}$ concentrations increase markedly within hours after birth in the human, but the high serum $\mathrm{rT}_{3}$ concentrations remain elevated for several weeks (20). Also, reduced serum $\mathrm{T}_{3}$ but normal, rather than elevated, $\mathrm{rT}_{3}$ concentrations have been reported in some other clinical situations ( 7 , 21,62 ). These findings suggest that $T_{4}$ to $T_{3}$ converting $\left(\mathrm{T}_{4}-5^{\prime}\right.$-deiodinase) and $\mathrm{rT}_{3}$ degrading $\left(\mathrm{rT}_{3}-5^{\prime}\right.$-deiodinase) activities are dissociable, and thus may be separate enzymes. The question can ultimately be resolved only by subcellular localization and purification of the enzyme(s).

\section{ACKNOWLEDGMENTS}

We thank Mrs. Leona Fields, Ms. Kathleen Kelley, and especially Mrs. Nancy Hykel-Malone for expert technical assistance and Mrs. Elaine Paolini and Ms. Mary Saxon for able secretarial help.

This work was supported by U. S. Public Health Service grant AM 14039. Reagents for the rat TSH radioimmunoassay were provided by the Rat Pituitary Hormone Program of the National Pituitary Agency, National Institute of Arthritis, Metabolism, and Digestive Diseases of the National Institutes of Health.

\section{REFERENCES}

1. Albert, A., and F. R. Keating, Jr. 1952. The role of the gastrointestinal tract, including the liver, in the metabolism of radiothyroxine. Endocrinology. 51: 427-435.

2. Oppenheimer, J. H., H. L. Schwartz, H. C. Shapiro, G. Bernstein, and M. I. Surks. 1970. Differences in primary cellular factors influencing the metabolism and distribution of $3,5,3^{\prime}$-L-triiodothyronine and L-thyroxine. J. Clin. Invest. 49: 1016-1024.

3. Surks, M. I., and J. H. Oppenheimer. 1971. Metabolism of phenolic- and tyrosylring labeled L-thyroxine in human beings and rats. J. Clin. Endocrinol. Metab. 33: $612-618$.

4. Chopra, I. J. 1976. An assessment of daily production and significance of thyroidal secretion of $3,3^{\prime}, 5^{\prime}$-triiodothyronine (reverse $\mathrm{T}_{3}$ ) in man. J. Clin. Invest. 58: 32-40.

5. Carter, J. N., C. J. Eastman, J. M. Corcoran, and L. Lazarus. 1974. Effect of severe chronic illness on thyroid function. Lancet. II: 971-974.

6. Bermudez, F., M. I. Surks, and J. H. Oppenheimer. 1975. High incidence of decreased serum triiodothyronine concentration in patients with non-thyroidal disease. J. Clin. Endocrinol. Metab. 41: 27-40.

7. Chopra, I. J., U. Chopra, S. R. Smith, M. Reza, and D. H. Solomon. 1975. Reciprocal changes in serum concentrations of $3,3^{\prime}, 5^{\prime}$-triiodothyronine (reverse $T_{3}$ ) and $3,3^{\prime}, 5$ triiodothyronine $\left(\mathrm{T}_{3}\right)$ in systemic illnesses. J. Clin. Endocrinol. Metab. 41: 1043-1049.

8. Burger, A., P. Nicod, P. Suter, M. B. Valloton, A. Vagenakis, and L. Braverman. 1976. Reduced active thyroid hormone levels in acute illness. Lancet. I: 653-655.

9. Spector, D. A., P. J. Davis, J. H. Helderman, B. Bell, and R. D. Utiger. 1976. Thyroid function and metabolic 
state in chronic renal failure. Ann. Intern. Med. 85: $724-730$.

10. Wartofsky, L., K. D. Burman, R. C. Dimond, G. L. Noel, A. G. Frantz, and J. M. Earll. 1977. Studies on the nature of thyroid suppression during acute falciparum malaria: integrity of pituitary response to TRH and alterations in serum $\mathrm{T}_{3}$ and reverse $\mathrm{T}_{3} . \mathrm{J}$. Clin. Endocrinol. Metab. 44: 85-90.

11. Duick, D. S., D. W. Warren, J. T. Nicoloff, C. L. Otis, and M. S. Croxon. 1974. Effect of single dose dexamethasone on the concentration of serum triiodothyronine in man. J. Clin. Endocrinol. Metab. 39: 11511154.

12. Chopra, I. J., D. E. Williams, J. Orgiazzi, and D. H. Solomon. 1975. Opposite effects of dexamethasone on serum concentrations of $3,3^{\prime}, 5^{\prime}$-triiodothyronine (reverse $\left.\mathrm{T}_{3}\right)$ and 3,3'-5-triiodothyronine $\left(\mathrm{T}_{3}\right) . J$. Clin. Endocrinol. Metab. 41: 911-920.

13. Saberi, M., F. H. Sterling, and R. D. Utiger. 1975. Reduction in extrathyroidal triiodothyronine production by propylthiouracil in man. J. Clin. Invest. 55: 218-223.

14. Geffner, D. L., M. Azukizawa, and J. M. Hershman. 1975. Propylthiouracil blocks extrathyroidal conversion of thyroxine to triiodothyronine and augments thyrotropin secretion in man. J. Clin. Invest. 55: 224-229.

15. Burger, A., D. Dinichert, P. Nicod, M. Jenny, T. Lemarchand-Béraud, and M. B. Vallotton. 1976. Effect of amiodarone on serum triiodothyronine, reverse-triiodothyronine, thyroxine and thyrotropin. J. Clin. Invest. 58: 255-259.

16. Bürgi, H., C. Wimpfheimer, A. Burger, W. Zaunbauer, H. Rösler, and T. Lemarchand-Béraud. 1976. Changes in circulating thyroxine, triiodothyronine and reverse triiodothyronine after radiographic contrast agents. $J$. Clin. Endocrinol. Metab. 43: 1203-1210.

17. Portnay, G. I., J. T. O'Brien, J. Bush, A. G. Vagenakis, F. Azizi, R. A. Arky, S. H. Ingbar, and L. E. Braverman. 1974. The effect of starvation on the concentration and binding of thyroxine and triiodothyronine in serum and on the response to TRH. J. Clin. Endocrinol. Metab. 39: $191-194$.

18. Vagenakis, A. G., A. Burger, G. I. Portnay, M. Rudolf, J. T. O'Brian, F. Azizi, R. A. Arky, P. Nicod, S. H. Ingbar, and L. E. Braverman. 1975. Diversion of peripheral thyroxine metabolism from activating to inactivating pathways during complete fasting. J. Clin. Endocrinol. Metab. 41: 191-194.

19. Moshang, T., Jr., J. S. Parks, L. Baker, V. Vaidya, R. D. Utiger, A. M. Bongiovanni, and P. J. Snyder. Low serum triiodothyronine in patients with anorexia nervosa. $J$. Clin. Endocrinol. Metab. 40: 470-472.

20. Chopra, I. J., J. Sack, and D. A. Fisher. 1975. Circulating $3,3^{\prime}, 5^{\prime}$-triiodothyronine in the human newborn. J. Clin. Invest. 55: 1137-1141.

21. Nicod, P., A. Burger, V. Staeheli, and M. B. Vallotton. 1976. A radioimmunoassay for $3,3^{\prime}, 5^{\prime}$-triiodo-L-thyronine in unextracted serum: Method and clinical results. J. Clin. Endocrinol. Metab. 42: 823-829.

22. Eisenstein, A., S. Hagg, A. Vagenakis, S. Fang, L. Braverman, and S. Ingbar. 1977. Observations on the peripheral metabolism of $3,3^{\prime}, 5^{\prime}$-triiodothyronine (reverse $\mathrm{T}_{3}, \mathrm{rT}_{3}$ ) in fed and fasted patients. Clin. Res. 25: 294A. (Abstr.)

23. Chopra, I. J., S. Sack, and D. A. Fisher. 1975. 3,3',5'triiodothyronine (reverse $\mathrm{T}_{3}$ ) and, 3,3',5-triiodothyronine $\left(T_{3}\right)$ in fetal and adult sheep: Studies of metabolic clearance rates, production rates, serum binding, and thyroidal content relative to thyroxine. Endocrinology. 97: $1080-1088$.

24. Albright, E. C., and F. C. Larson. 1959. Metabolism of L-thyroxine by human tissue slices. J. Clin. Invest. 38: 1899-1903.

25. Hillier, A. P. 1972. Deiodination of thyroid hormones by the perfused rat liver. J. Physiol. (Lond.). 222: 475-485.

26. Visser, T. J., I. van der Does-Tobé, R. Docter, and G. Hennemann. 1975. Conversion of thyroxine into triiodothyronine by rat liver homogenate. Biochem. J. 150: $489-93$.

27. Chopra, I. J. 1977. A study of extrathyroidal conversion of thyroxine $\left(\mathrm{T}_{4}\right)$ to $3,3^{\prime}, 5$-triiodothyronine $\left(\mathrm{T}_{3}\right)$ in vitro. Endocrinology. 101: 453-463.

28. Nakagawa, S., and W. R. Ruegamer. 1967. Properties of a rat tissue iodothyronine deiodinase and its natural inhibitor. Biochemistry. 6: 1249-1261.

29. Sterling, K., M. A. Brenner, and V. F. Saldanha. 1973. Conversion of thyroxine to triiodothyronine by cultured human cells. Science (Wash. D. C.). 179: 10001001.

30. Chiraseveenuprapund, S., V. Buergi, A. Goswami, and I. N. Rosenberg. 1975. Formation of triiodothyronine from 1-thyroxine in rat kidney homogenate. In Thyroid Research. Proceedings of the Seventh International Thyroid Conference. J. Robbins and L. E. Braverman, editors. American Elsevier Publishing Co., Inc., New York. 244-247.

31. Rabinowitz, J. L., and E. S. Hercker. 1971. Thyroxine: conversion to triiodothyronine by isolated perfused rat heart. Science (Wash. D. C.). 173: 1242-1243.

32. Tata, J. R. 1957. Metabolism of $L$-thyroxine and 1-3:5:3'triiodothyronine by homogenates of rat skeletal muscle. Proc. Soc. Exp. Biol. Med. 95: 362-364.

33. Klebanoff, S. J., and W. L. Green. 1973. Degradation of thyroid hormones by phagocytosing human leukocytes. J. Clin. Invest. 52: 60-72.

34. Woeber, K. A. 1976. A granule-associated L-thyroxine deiodinating system in the human leukocyte. Endocrinology. 98: 802-806.

35. Refetoff, S., R. Matalon, and M. Bigazzi. 1972. Metabolism of L-thyroxine $\left(\mathrm{T}_{4}\right)$ and L-triiodothyronine $\left(\mathrm{T}_{3}\right)$ by human fibroblasts in tissue culture: evidence for cellular binding proteins and conversion of $\mathrm{T}_{4}$ to $\mathrm{T}_{3}$. Endocrinology. 91: 934-947.

36. Cavalieri, R. R., L. A. Gavin, F. Mc Mahon, and M. Hammond. 1977. Thyroxine $\left(\mathrm{T}_{4}\right)$ deiodination in liver: subcellular localization of reverse $\mathrm{T}_{3}\left(\mathrm{RT}_{3}\right)$ forming and degrading systems. Clin. Res. 25: 462A. (Abstr.)

37. Stanbury, J. B., M. L. Morris, H. J. Corrigan, and W. E. Lassiter. 1960. Thyroxine deiodination by a microsomal preparation requiring $\mathrm{Fe}^{++}$, oxygen, and cysteine or glutathione. Endocrinology. 67: 353-362.

38. Nakano, M., Y. Tsutsumi, and Y. Ushijima. 1971. Degradation of thyroxine by the microsomal particles from rat liver. Biochim. Biophys. Acta. 252: 335-347.

39. Hesch, R. D., G. Brunner, and H. D. Söling. 1975. Conversion of thyroxine $\left(\mathrm{T}_{4}\right)$ and triiodothyronine $\left(\mathrm{T}_{3}\right)$ and the subcellular localisation of the converting enzyme. Clin. Chim. Acta. 59: 209-213.

40. Chopra, I. J., S. Y. Wu, and D. H. Solomon. 1976. Extrathyroidal production of 3,3'-diiodothyronine $\left(T_{2}\right)$ in vitro: a major pathway of $\mathrm{rT}_{3}$ metabolism, a minor pathway for $T_{3}$. Program of the 58th Annual Meeting of the Endocrine Society. 102. (Abstr.)

41. Henninger, R. W., F. C. Larson, and E. C. Albright. 1968. Iodine-containing compounds of extrathyroidal tissues. J. Clin. Invest. 42: 1761-1768. 
42. Segel, I. 1975. Enzyme kinetics: behavior and analysis of rapid equilibrium and steady state enzyme systems. John Wiley and Sons, Inc., New York. 57.

43. Lieblich, J. M., and R. D. Utiger. 1972. Triiodothyronine radioimmunoassay. J. Clin. Invest. 51: 157-166.

44. Chopra, I. J. 1972. A radioimmunoassay for measurement of thyroxine in unextracted serum. J. Clin. Endocrinol. Metab. 34: 938-947.

45. Kaplan, M. M., M. Schimmel, and R. D. Utiger. 1977. Changes in serum 3,3',5'-triiodothyronine (reverse $\mathrm{T}_{3}$ ) concentrations with altered thyroid hormone secretion and metabolism. J. Clin. Endocrinol. Metab. 47: $447-456$.

46. Lowry, O. H., N. J. Rosebrough, A. L. Farr, and J. Randall. 1951. Protein measurement with Folin phenol reagent. J. Biol. Chem. 193: 265-275.

47. Frumess, R. D., and P. R. Larsen. 1975. Correlation of serum triiodothyronine $\left(T_{3}\right)$ and thyroxine $\left(T_{4}\right)$ with biologic effects of thyroid hormone replacement in propylthiouracil-treated rats. Metab. Clin. Exp. 24: 547554.

48. Hüfner, M., and M. Knöpfle. 1976. Pharmacological influences on $\mathrm{T}_{4}$ to $\mathrm{T}_{3}$ conversion in rat liver. Clin. Chim. Acta. 72: 337-341.

49. Kobayashi, I., T. Yamada, and K. Shichijo. 1966. Nonenzymatic deiodination of thyroxine in vitro. Metab. Clin. Exp. 15: 1140-1148.

50. Nicod, P., A. Burger, G. Strauch, A. G. Vagenakis, and L. E. Braverman. 1976. The failure of physiologic doses of reverse $\mathrm{T}_{3}$ to effect thyroid-pituitary function in man. J. Clin. Endocrinol. Metab. 43: 478-481.

51. Oppenheimer, J. H., H. I. Schwartz, and M. I. Surks. 1972. Propylthiouracil inhibits the conversion of Lthyroxine to L-triiodothyronine. J. Clin. Invest. 51: 24932497.

52. Taurog, A. 1976. The mechanism of action of the thioureylene antithyroid drugs. Endocrinology. 98: 10311046 .

53. Dratman, M. B., F. L. Crutchfield, E. Marsh, J. Axelrod, and F. H. Sterling. 1975. Iodothyronine metabolism and catecholamine enzymes: effect of alpha-methyl-paratyrosine in thyroidectomized euthyroid rats. In Thyroid Re- search. Proceedings of the Seventh International Thyroid Conference. J. Robbins and L. E. Braverman, editors. American Elsevier Publishing Co., Inc., New York. 248-250.

54. Fisher, D. A., and J. Sack. 1975. Thyroid function in the neonate and possible approaches to newborn screening for hypothyroidism. In Perinatal Thyroid Physiology and Disease. D. A. Fisher and G. N. Burrow, editors. Raven Press, New York. 197-209.

55. Hillier, A. P. 1974. Antagonistic effects of dinitrophenol and cyanide on hepatic thyroxine deiodination. Acta Endocrinol. 77: 122-127.

56. Campbell, G. A., M. Kurcz, S. Marshall, and J. Meites. 1977. Effects of starvation in rats on serum levels of follicle stimulating hormone, luteinizing hormone, thyrotropin, growth hormone and prolactin, response to $\mathrm{LH}$ releasing hormone and thyrotropin-releasing hormone. Endocrinology. 100: 580-587.

57. Schussler, G. C. 1966. Paradoxical effects of starvation and cortisone administration on free thyroxine concentration and thyroxine metabolism. J. Clin. Invest. 45: 1072. (Abstr.)

58. Ingbar, D. H., and V. A. Galton. 1975. The effect of food deprivation on the peripheral metabolism of thyroxine in rats. Endocrinology. 96: 1525-1532.

59. Balsam, A., F. Sexton, and S. H. Ingbar. 1977. Independent inhibitory effects of hypothyroidism and fasting on hepatic conversion of thyroxine $\left(\mathrm{T}_{4}\right)$ to triiodothyronine $\left(\mathrm{T}_{3}\right)$ in the rat. Program of the 59th Annual Meeting of the Endocrine Society. 239. (Abstr.)

60. Wilber, J. F., and R. D. Utiger. 1969. The effect of glucocorticoids on thyrotropin secretion. J. Clin. Invest. 48: 2096-2103.

61. Koch, B., M. Jobin, S. Dulac, and C. Fortier. 1972. Thyrotropin (TSH) response to synthetic TSH-releasing factor following pharmacologic blockade of adrenocorticotropin secretion. Can. J. Physiol. Pharmacol. 50: 360363.

62. Spaulding, S. W., I. J. Chopra, R. S. Sherwin, and S. S. Lyall. 1976. Effect of caloric restriction and dietary composition on serum $\mathrm{T}_{3}$ and reverse $\mathrm{T}_{3}$ in man. $J$. Clin. Endocrinol. Metab. 42: 197-200. 